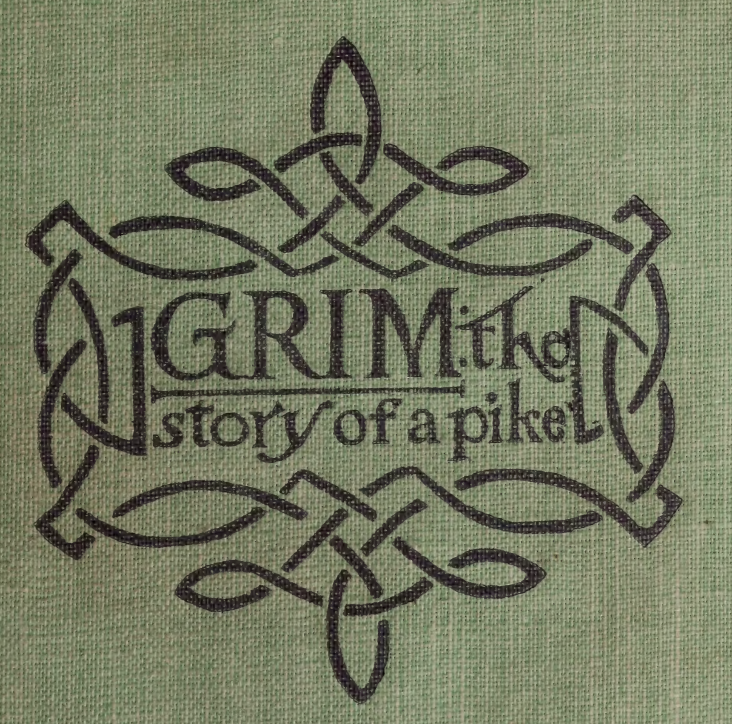




$$
\text { \% }
$$


$\mathbb{A} 2^{2} 1^{2}$ 





\section{Grim: The Story of a Pike}


П $\mathrm{HE}$ firm of Gyldendal [Gyldendalske [ Boghandel Nordisk Forlag] is the oldest and greatest publishing house in Scandinavia, and has been responsible, since its inception in 1770 , for giving to the world some of the greatest Danish and Norwegian writers of three centuries. Among them are such names as Ibsen, Bjфrnstjerne Bjфrnson, Pontoppidan, Brandes, Gjellerup, Hans Christian Andersen, and Knut Hamsun, the Nobel Prize winner for 1920, whose works I am publishing in America.

It is therefore with particular satisfaction that I announce the completion of arrangements whereby I shall bring out in this country certain of the publications of this famous house. The books listed below are the first of the Borzoi-Gyldendal books.

\section{Jenny}

A novel translated from the Norwegian of Sigrid Undset by W. Emmé.

\section{The Sworn Brothers}

A Tale of the Early Days of Iceland. Translated from the Danish of Gunnar Gunnarsson [Icelandic] by C. Field and W. Emmé.

\section{Grim: the Story of a Pike}

ALFRED A. KNOPF, Publisher, NEW YORK 



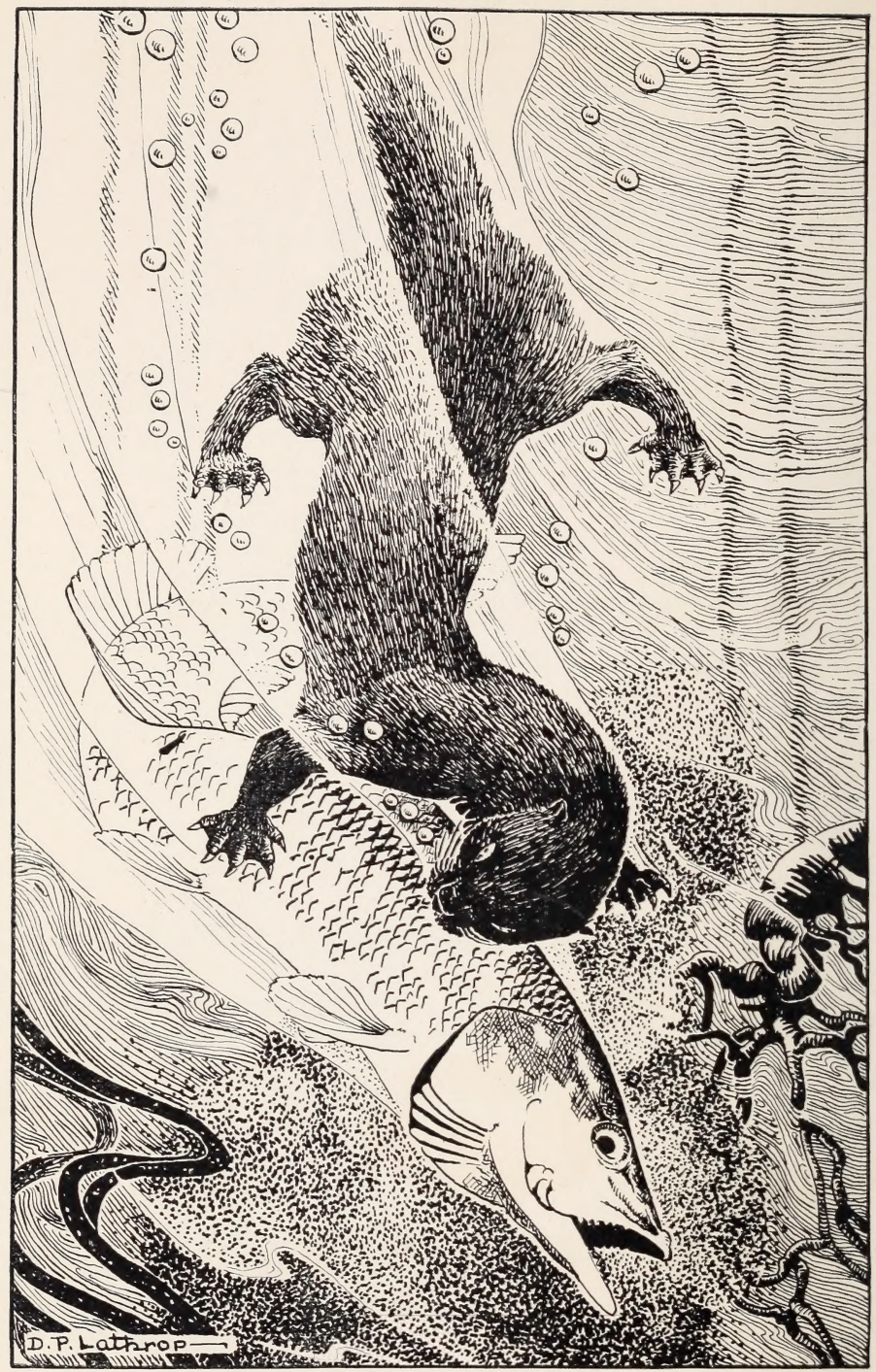

"A wild chase was going on in the depths, and where it passed the rushes bowed their sheaves." 


\section{Grim: The Story of a Pike}

Translated from the Danish of Svend Fleuron by $\mathrm{J}$. Muir and $\mathrm{J}$. Alexander

Illustrated by Dorothy P. Lathrop

New York

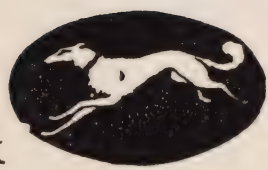

Mcmxxi

Alfred $\cdot A \cdot K n o p f$ 


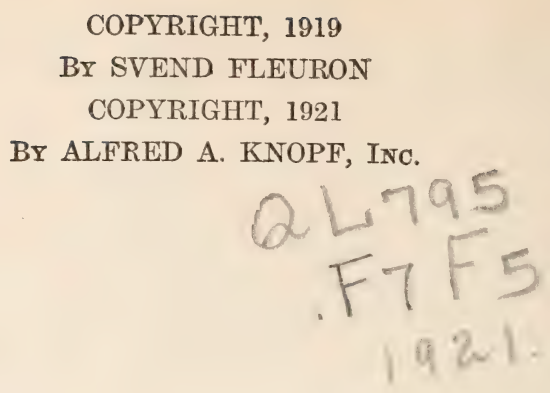

Original Title: Grum

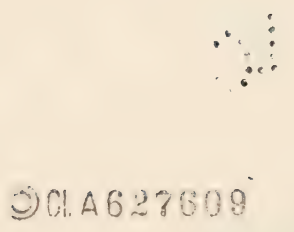

PRTNTED IN THE UNITED STATES OF AMERICA

AUG -8 '21 


\section{$7 \mathrm{O}$ devour others and to avoid being de- voured oneself, that is life's end and 1 aim.}





\section{CONTENTS}

I. LIFE, II

II. In the Shelter of the Creek, 2 I

III. Grim Goes Exploring, 32

IV. The Marauders, 45

V. The Pearly Fish, 57

VI. The Man-Roach, 74

VII. The Rasper, 90

VIII. The Angler's End, IO5

IX. The Wedding Festival, 115

X. In the Marsh, 123

XI. Terror, 138

XII. Grim Develops, 144

XIII. A Fight with an OtTer, 157

XIV. The Angler from Town, i67

XV. Luck! I76 



\section{ILLUSTRATIONS}

A wild chase was going on in the depths, and where it passed the rushes bowed their sheaves. (Frontispiece.)

With a hiss it curves its neck and turns the foil upwards, snapping and biting at its tormentors.

Facing page I7

She snaps eagerly at the nearest "worm," but it escapes her by adroitly curling up.

Facing page 42

The bird darts upon her from behind with outstretched claws, and drives them with full force into her back.

Facing page 153 



\section{I: LIFE}

OLEAR running water filled the ditch, 1 but the bottom was dull black, powdery mud. It lay inches deep, layer upon layer of one tiny particle upon another, and so loose and light that a thick, opaque, smoke-like column ascended at the slightest touch.

A monster, with the throat and teeth of a crocodile, a flat, treacherous forehead, and large, dull, malicious eyes, was lying close to the bottom in the wide, sun-warmed crossdyke that cut its way inland from the level depths of the great lake. The entire monster measured scarcely a finger's length.

The upspringing water-plants veiled her body and drew waving shadows over her round, slender tail.

When the sun was shining she liked to stay here among the bottom vegetation and imitate a drifting piece of reed. Her reddish-brown colour with the tiger-like transverse stripes 
made an excellent disguise. She simply was a piece of reed. Even the sharp-eyed heron, which had dropped down unnoticed about a dozen yards off, and was now noiselessly, with slow, cautious steps, wading nearer and nearer, took her at the first glance for a stick.

All the ditch-water life of a summer day was pulsating around the young pike.

Water-spiders went up for air and came down with it between their hind legs, to moor their silvery diving-bells beneath the whorls of the water-moss. One boat-bug after another, with a shining air-bubble on its belly to act as a swimming-bag, and for oars a pair of long legs sticking far out at the sides, darted with great spurts through the water, or rose and sank with the speed of a balloon. The young pike peered upwards, and saw in the shelter of a tuft of rushes a collection of black, boat-shaped whirligigs, showing like dots against the shining surface. The little waterbeetles lay and dozed; but all at once a sudden storm seemed to descend upon them and they scattered precipitately, whirling away in wider and wider circles, only to congregate 
again just as suddenly, like a flock of sheep.

The young pike disappeared from the heron's view in a cloud of mud, and glided off to some distance, finally coming to anchor on a wide submerged plain in a broad creek, shadowed by a clump of luxuriant marsh marigolds, whose yellow flowers gleamed out from among the clusters of green, heart-shaped leaves.

There was never any peace around her. When one animal was on its way down, another would be on its way up. And the bed of ooze beneath her was in incessant motion. Sticks moved to right and left; hairy balls lay and rolled over one another ; there was a twisting and turning of larvae in all directions. The active water-beetles were dredging incessantly, releasing leaves and stalks which slowly and weirdly rose to the surface. Airbubbles, too, were set free, and ascended quickly with a rotary motion.

Here two large tiger-beetles were fighting with a poor water-bug. The flat-bodied insect stretched out its scorpion-like claws towards its enemies, but the tiger-beetles seized 
it one at each end, beat off its claws with their strong palpi, and tore its head from its body It must have been almost a pleasure to fin: oneself so neatly despatched!

Everything tortured and killed down here, some, indeed, even devoured themselves. To lose arms and legs and flesh from their body was all in the order of the day; and anything resting for but a minute was taken for carrion.

The big horse-leech had wound its rhythmically serpentine way through the water It was tired now, and had just stretched itself out for a moment's rest, when the supposed pieces of stick upon which it lay seized it, and voracious heads with sharp jaws attacked it flesh. It was within an ace of being made captive for ever, but at last succeeded in making its escape and pushing off, with two of its tormentors after it.

The young pike watched attentively the flight of the black leech. She saw that to devour others and to avoid being devoured oneself was the end and aim of life.

For a long time she remained quite still, 
only an undulating movement of the dorsal fin ind the malicious glitter of the eyes revealing b.r vitality. Slowly she opened and closed $r$ small, wide mouth, and let the oxidizing vater flow over her blood-red gills.

It was not long before she had forgotten her ecent peril, and once more became filled with he cruel passion of the hunter.

From the shadow of the marsh marigolds he darted under the newly unfolded leaf of a vater-lily. This was a very favourite lurkig-place; she could lie there with her back ight up against the under surface of the leaf, ind her snout on the very border of its shadow, eady to strike. The silvery flash of small sh twinkled around her, and myriads of tiny hining crustaceans whisked about so close to ier nose that at any moment she could have napped them up by the score into her voraious mouth.

It was especially things that moved that Iad a magic attraction for Grim. From the ime when, but twelve to fifteen days old, she ad consumed the contents of her yolksac, and pened her large voracious mouth, everything 
that flickered, twisted and moved, all that sought to escape, aroused her irresistible desire.

In the innermost depths of her being there was an over-mastering need, expressing itself in an insatiableness, a conviction that she could never have enough, and a fear that others would clear the waters of all that was eatable. An insane greed animated her; and even when she had eaten so much that she could eat no more, she kept swimming about with spoil in her mouth.

On the other hand, anything at rest and quiet possessed little attraction for her; she felt no hunger at sight of it, and no desire to possess it: that she could take at any time.

- Meanwhile, the keen-eyed heron, wading up to its breast in the water, comes softly and silently trawling through the ditch.

Sedately it goes about its business, stalking along with slow, measured steps. Its big, seemingly heavy body sways upon its thin, greenish yellow legs, its short tail almost combing the surface of the water, while its long, round neck is in constant motion, direct- 



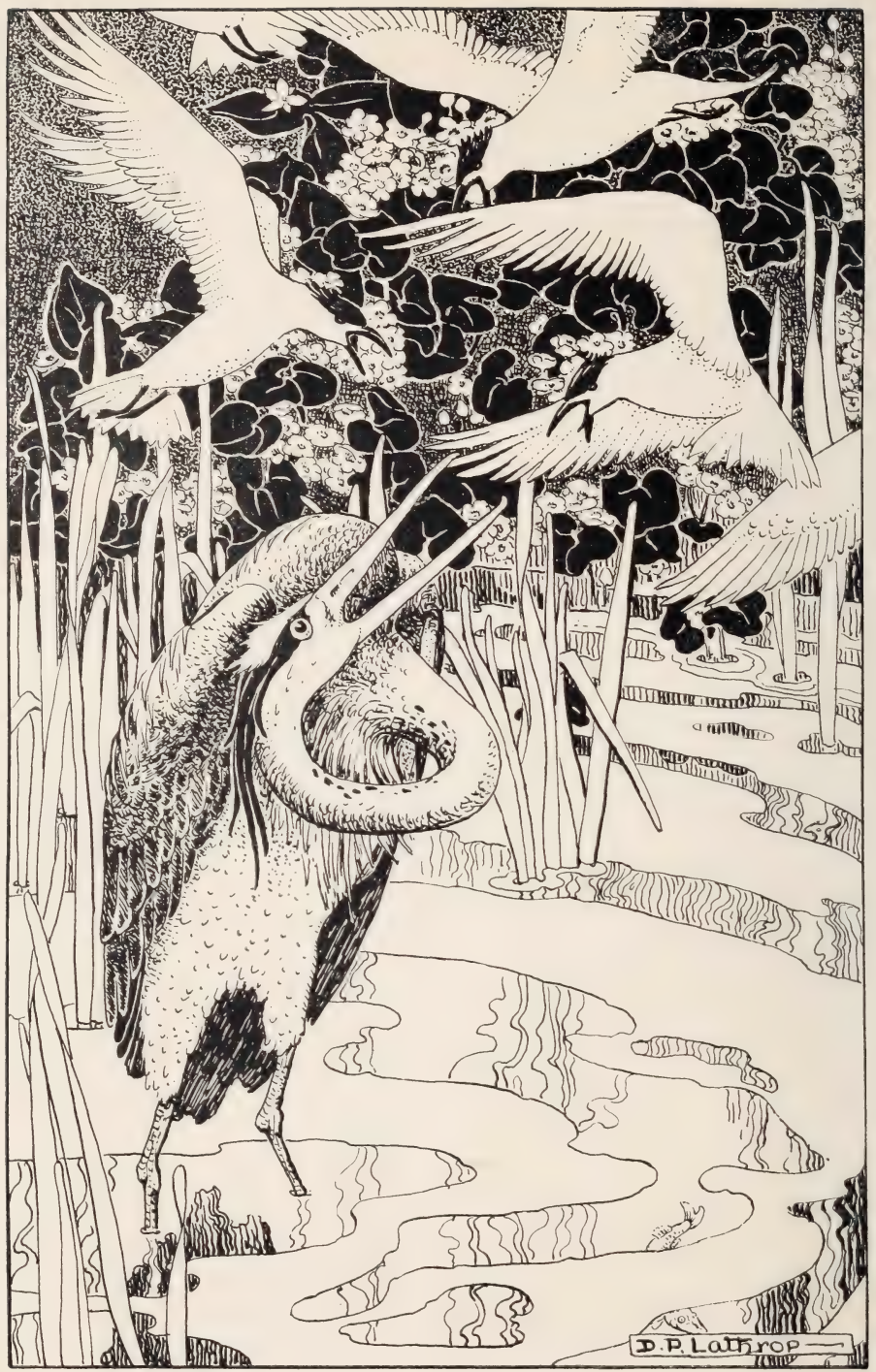

"With a hiss it curves its neck and turns the foil upwards, snapping and biting at its tormentors." 
ing the dagger-like beak like a foil into all kinds of attacking positions.

Sea-crows and terns scream around it, and from time to time three or four of them unite in harrying their great rival. Just as the heron has brought its beak close to the surface of the water, ready to seize its prey, the gulls dash upon it from behind. With a hiss it curves its neck and turns the foil upwards, snapping and biting at its tormentors.

An irritating little flock of gulls may go on thus for a long time; and when at last, screaming and mocking, they take their departure, they have spoilt many a chance and wasted many precious minutes of the big, silent, patient fisher's time.

The gulls once gone, the heron applies itself with redoubled zeal to its business. From various attacking positions its beak darts down into the water, but often without result, and it has to go farther afield; then at last it captures a little eel.

It is not easy, however, to swa!low the wriggling captive. The eel twists, and refuses to be swallowed; so the bird has to 
reduce its liveliness by rolling up and down in its sharp-edged beak. Then it glides down.

This time, too, fortune is disposed to favour the young pike. The heron, coming up behind her, cautiously bends its neck over the drifting piece of reed. It sees there is something suspicious about it, but thinks it is mistaken, and is about to take another step forward. When only half-way, it pauses with its foot in the air; and the next moment the blow falls.

Grim only once moved her tail. Then she was seized, something hard and sharp and strong held her fast, and she passed head foremost down into a warm, narrow channel.

There was a fearful crush of fish in the channel, and much elbowing with fins and twisting of tails. Something behind her was pushing, but the throng in front blocked the way: she could get no farther.

And yet she glided on! Very slowly the thick slimy water in the channel bore the living, muddy tangle that surrounded her along; she felt the corners of her mouth rub against 
the sides of the channel; she could scarcely breathe.

In the meantime the heron was flying homewards to its young, carrying Grim and the rest of the catch. Out on the lake lay a boat in which a man sat fishing. Experience told the bird it was a fisherman, but here the bird was wrong. The man had a gun in the boat, and as the bird sailed upwards a shot was fired which compelled it to relinquish a part of its booty in order to escape more quickly.

Grim was among the fortunate ones. Suddenly the crush in the long, dark channel grew less, and the sluggish stream of mud that was bearing her along changed its course. A little later the stream gathered furious pace and carried her with it; she saw light and felt space round her; she was able to move her fins.

Then she fell from the heron's beak, from a height of about twenty yards. She had time to notice how suffocatingly dry the other world was. It seemed to draw out her entrails, and all her efforts to right herself were in vain. 
Then she regained her native element; water covered her gills, and she could begin to swim. 


\section{II: IN THE SHELTER OF THE CREEK}

RIM was a year old when her scales

J began to grow.

In her early youth, when she could only eat small creatures, she had lived exclusively upon water-insects and larvae; but from now onwards she had no respect for any flesh but that which clothed her own ribs.

She attacked any fish that was not big enough to swallow her, and devoured bleak and small roach with peculiar satisfaction. Now she took her revenge on the voracious small fry that had offended her when she was still in an embryo state.

She had not been hatched artificially, or come in to the world in a wooden box with running water passing through it. No, the whole thing had taken place in the most natural manner.

In the flickering sunshine of a March day, 
her mother, surrounded by three equally ardent wooers, had spawned, and the eggs had dropped and attached themselves to some tufts of grass at the edge of the lake. The very next day, however, little fish had begun to gather about those tufts; one day more, and there were swarms of them. Eagerly they searched the tufts and devoured all the eggs they could find; and so thoroughly did they go about their business, that of the thousands upon thousands of the mother's eggs, only two that had fallen into the heart of a grass-stalk were left.

Out of one of these Grim had come. The sun had looked after her, hatched her out, and taught her to seize whatever came in her way. Now she was avenging the injuries to her tribe.

She possessed a remarkable power of placing herself, and knew how to choose her position so as to disappear, as it were, in the water. The stalks of the reeds threw their shadows across her body in all directions; water-grass and drifting duck-weed veiled her; the silly roach and other restless little fish flitted about 
her, sometimes so close to her mouth that she could feel the waves made by their tail-fins. Some would almost run right into her; but when they saw her, then how the water flashed with starry gleams, and how quickly they all made off!

She liked best to hide where the water-lilies floated in islands of green, for there the treacherous shadows-her best friends-fell clearly through the water; absorbed her, as it were, and made capture easy for her. If she found herself discovered, she would retreat with as little haste as possible; for that sort of thing aroused too much attention, and created widespread disturbance in the fishy world.

If she lay on the surface, for instance, and suspected that she was being watched from above, she became, as it were, more and more indistinct and one with the dark water, letting herself sink imperceptibly, at the same time beginning to work all her fins. In ample folds they softly crept round the long stick that her body now resembled, fringed and veiled it and bore it away.

And just as she knew how to. place herself, 
so did she know how to move-cautiously and discreetly.

Formerly she had measured only a finger's length, and now she was already about a foot long; her voraciousness had increased in a corresponding degree. She could eat every hour of the day. She would fill herself right up to the neck, and even have half a fish sticking out beyond. It was quite a common sight to see a little flapping fish-tail for which her digestive organs had not room as yet, sticking out of her mouth like a lively tongue. She would swim about delightedly, sucking it as a boy would suck a stick of candy.

One day she was gliding slowly through a clump of rushes, as lifeless and dead as any stick. Her eyes seemed to be on stalks and spied eagerly round, but her body exhibited the least possible movement and eagerness.

She turned, but even then holding herself stiff, and playing her new part of a drifting stick in a masterly manner. As she did so she discovered her brother, as promising a specimen of a young pike as herself, with all the distinguishing marks of the race. 


\section{THE CREEK}

Although cold-blooded, she was of a fiery temperament, and as she was also hungry, she stared greedily and with cannibal feelings at the apparition. Her appetite grew in immeasurable units of time. The food was at hand, it stared her in the face; she forgot relationship and resemblance, and bending in the middle so that head and tail met, she seized her brother with a lightning movement.

He was quite as big as she, struggled until he was unable to move a fin; but the stroke was successful.

She began to understand things, and giew ever fiercer and more violent and voracious. Her teeth were doubled, and as they grew they were sharpened by the continual suction of the water through the gills. It was as if she understood their value, too, for she would often take up her position on the bottom and stir up grains of fine, hard sand, thus improving the grinding process considerably.

It was mostly in the half-light that she now went hunting, in the early dawn or at dusk. Her sharp eyes could see in the dark like those of the owl and the cat. When the shadows 
lengthened, and the red glow from the sky spread over the water, she felt how favourable her surroundings were, and she became one with the power in her mighty nature.

But in the daytime, she lay peacefully drowsing.

The creek in which she lived had low-lying banks.

Among the short, thick grass, orchids and marsh marigolds bloomed side by side, and the ragged robin unfolded its frayed, deep pink flowers upon a stiff, dark brown stalk, that always had a mass of frothy wetness about its head.

Farther out, the muddy water and horsetails began, and beyond them the tall, waving reeds, which stretched away in great clumps as far as it was possible for them to reach the bottom.

Where they left off, the round-stalked olivegreen bog rushes began, wading farther and farther out, until in midstream they gathered in low clumps and groves, inhabited by an abundant insect life. 
Beautiful butterflies danced their bridal dance out there, some bright yellow with black borders, others with the sunset glow upon their wings. Dragon-flies and water-nymphs by the score refracted the sun's rays as they turned with a flash of all the colours of the rainbow. Black whirligigs lay in clusters and slept; and on the indiarubber-like leaves of the water-lily, flies and wasps crawled about dry-shop, and refreshed themselves with the water.

In the still, early morning the reeds sigh and tremble. The little yellowish grey sedgewarbler comes out suddenly from its hidingplace, seizes the largest of the butterflies by the body, and as suddenly disappears again. A little later it begins its soft little sawing song, which blends so well with the perpetual, monotonous whispering of the reeds.

Grim, down among the vegetation, only faintly catches the subdued tones; she is occupied with an event that is developing with great rapidity.

A moth has fallen suddenly into the clear water. It tries to rise, but cannot, so darts 
rapidly across the surface of the water, dragging its tawny wings behind it. It puts forth its greatest speed, making in a straight line for the shore.

But the whirligigs have seen the shipwreck, and dart out on their water-ski to tear the thing to pieces. They advance with the speed of a torpedo-boat, and in peculiar spiral windings. A wedge-shaped furrow stands out from the bow of each little pirate, and a tiny cascade in his wake.

The poor moth becomes wetter and wetter, and less and less of his body remains visible as he exerts himself to reach the safety of the reeds, where he can climb up into a horse-tail and escape, just as a cat climbs into a tree to escape from a dog.

Unfortunately he does not succeed; he is in a sinking condition, and one of the whirligigs fastens voraciously upon his hind quarters.

The successful captor, however, is given no peace in which to devour his prey. He has to let it go, and seize it, and let it go again; and now a little fish-a bleak-begins to take a part in the play. 
The fluttering chase continues noiselessly across the surface of the water, and urged on by the whirligigs above and the bleak beneath, the moth approaches the reeds.

With muscles relaxed and dorsal fin laid flat, Grim lies motionless at its edge, whence again and again she catches a glimpse of the little silvery fish.

Its delicate body is fat outside and in, plump and well nourished, and to the eyes of the fratricide is an irresistible temptation, making her hunger creep out to the very tips of her teeth.

Her dorsal fin opens out and is cautiously raised, while her eyes greedily watch the movements of the nimble little fish.

Flash follows flash, each bigger and brighter than the other.

Grim feels the excitement and ecstasy of the spoiler rush over her-all that immediately precedes possession of the spoil-and delights in the sensation. She begins to change from her stick-like attitude, and imperceptibly to bend in the middle.

The plump little fish is too much en- 


\section{[30]}

grossed in its moth-hunt. Unconcernedly it lets its back display a vivid, bright green lakehue, while with its silvery belly it reflects all the rainbow colours of the water.

Another couple of seconds and the prey is near.

Then Grim makes her first real leap. It is successful. Ever since she was the length of a darning-needle, she had dreamt of this leap, dreamt that it would be successful.

The sedge-warbler in the reedy island heard the splash, and the closing snap of the jaws. They closed with such firmness that the bird could feel, as it were, the helpless sigh of the victim, and the grateful satisfaction of the promising young pirate.

She was the tiger of the water. She would take her prey by cunning and by craft, and by treacherous attack. She was seldom able to swim straight up to her food. How could she chase the nimbel antelopes of the lake when, timid and easily startled, they were grazing on the plains of the deep waters; they discovered her before she got near them and could begin her leap! 
Huge herds were there for her pleasure. She had no need to exert herself, but could choose her quarry in ease and comfort. The larger its size, and the greater the hunger and lust for murder that she felt within her, the more violence and energy did she put into the leap. But just as the falcon may miss its aim, so might she, and it made her ashamed, like any other beast of prey; she did not repeat the leap, but only hastened away.

But when her prey was struggling in her hundred-toothed jaws and slapping her on the mouth with its quivering tail-fin, then slowly, and with a peculiar, lingering enjoyment, she straightened herself out from her bent leaping posture. If she was hungry, she immediately swallowed her captive, but if not, she was fond, like the cat, of playing with her victim, swimming about with it in her mouth, twisting and turning it over, and chewing it for hours before she could make up her mind to swallow it.

She ate, she stuffed herself; and with much eating she waxed great. 


\section{III : GRIM GOES EXPLORING}

T $N$ the creek where she lived among rushes and reeds, a shoal of perch had their I abode. They were scarcely as big as she, but much thicker and older. Their leader in particular, by whose movements the whole flock were guided, was a broad bellied highbacked fellow, who knew the value of the weapon of defence he possessed in his strong, spiny dorsal fin.

He had a peculiar power of varying his colour so that it always suited the light in the water and on the bottom. There were days when he looked an emerald green, without any brassy tinge; at other times he let the black flickerings along his sides stand out like the stripes on a zebra's skin, and gave a brilliancy to his belly like that of the harvest moon. That was for fine weather. There was life in the water then!

But common to them all were the rough, 


\section{GRIM GOES EXPLORING [33]}

rasping scales that grew close up round the carroty-red fins, and the round yellow eyes with coal-black pupils, which seemed to rest on cushions and roll outside the head so that the fish could see both up and down.

The perch were quite as rapacious as Grim herself; they poached upon her small-fish preserves, and often disturbed her in the chase. Had she only been equal to it, she would gladly have devoured some of them, too.

One evening when she was so hungry that she under-estimated everything, she saw her chance of attacking their dark-hued leader, but Rasper, becoming aware of his dilemma, defended himself with the energy of a bulldog. The combat was on the point of turning in his favour, when Grim disappeared from view by taking a bold salmon-leap high into the air. After that they always swam scowling past one another at a respectful distance; but Grim was well aware that the striped swimmer had no friendly feeling towards her.

As she grew bigger, and felt herself more and more the powerful despot, whose dental armature had been provided simply and solely 


\section{[34]}

for the purpose of biting others, her hatred of the high-backed one instinctively became greater. They were of such widely different natures!

Grim was passionate, fierce, and reckless in her attacks, and gave herself up to the intoxicating pleasure of the chase until she grew dizzy. She ventured all, and lost herself in rapacious lust. The cunning perch seldom made a false step, but looked carefully ahead, and was always cool and self-restrained in his behaviour; and yet he was always ready —quite as ready as she-to attack, but had a masterly perception of the chances of success. He would frequently dart towards her, then suddenly stop and consider, and stand sniffing at her like a dog.

She was still only a hobbledehoy, flabby and loose-jointed, and not quick enough in emergencies. She had only just found out where the great ones of her own species liked to post themselves, and where it behoved her, therefore, to be on her guard; but beyond this she was not burdened with much experience.

As a young fish she had never been out into 


\section{GRIM GOES EXPLORING [35]}

deep water, but wisely kept to the quiet parts - the channels and the broad waters of the creek, where her strength was proportionate to the exigencies of her surroundings, and where she instinctively felt that her great enemies would run aground if they pursued her. Here she found shelter among the reeds and the rushes.

But there was something beyond; something great and strong, something always disquieting; and this attracted her.

She began to go farther and farther afield, and one day, when the water was especially bright and clear, she set out on a journey from one end of the lake to the other.

The bottom of the creek was fertile, hilly country. Long slopes, clothed with water-lily plants, and laden with yard-high, roundstalked grass, ran out in parallel chains, framing, as it were, a corresponding stretch of broad, deep valleys. Here and there were steep narrows, passes through which the shoals of fish had to venture when going from one pasture to another.

She swam just below the surface of the 
water, and looked with interest at the varied scenery of the bottom and all the unfamiliar and strange things that presented themselves. How delightful it was to let herself go and give her fins free play!

She reached a rocky reef, and swam over a group of high, wild mountains that rose steeply out of the black bottom ooze with rugged sides, wooded in parts, and in others barren and naked. The mountains were full of deep ravines, the ice of centuries of winters' freezing of the bottom had furrowed them with crests and clefts, planed off the points of the summits, and formed rounded tops or plateaux.

Here and there in this rocky land with its numerous winding inlets and sharp corners, a conspicuous stump stuck up. Several of them had a ring at one end, and from a few waved a bit of rope. In the course of time they had dropped down from the other world. They were lost boat-hooks and anchors that had become hopelessly fixed; for the rocky reef was a good fishing-ground.

There were many crayfish in the lake, and 
Grim, as she swam, had a bird's-eye view of them walking about, swarming over the bottom of the lake in all directions, laboriously measuring out the kilometres in crayfish steps.

In several places there were whole towns of them, and in the perpendicular cliffs on the deep side of the reef, there was a large crayfish population. Here she noticed certain specimens, larger than she cared about. They lay in wait among the rocks or in the depths of the primeval forest, and caught what fish they could in their deadly claws. Or they ran backwards through the water with claws and feelers extended, step by step and with a beat of the tail; if the waves they set up had not warned her in time, they might have run into her at any moment.

From the reef she passed on over a great sandy desert, where the worms lay in rings, and the fresh-water mussels in colonies. She came upon some unpretending and not very luxuriant plants with swinging stalks that could turn with the current and the waves; but what struck her most, and broke the monotony more than anything else, was the skeleton re- 
mains of anımals, boats, and a few human beings, that lay scattered about.

Where the substratum of the rocky reef still extended under the sand without disappearing altogether, she saw these slowly-perishing remains of the meteors from the air-world, lying scoured and clean as on a tray. In the eyeholes of the skulls the crayfish sheltered when they rested on their long journey over these perilous wastes, and perch lurked in the shadow of the ribs.

Farther out, where current and drifting sand alternately had the mastery, things were incessantly being uncovered and reburied; and in the middle of the desert waste, where there were quicksands, sometimes an arm would project from the sand-dunes, sometimes a leg, or the frontal bone of a skull bearing a huge pair of horns, or the prow of a boat. Finally, the desert ended in a whole skeleton reef-the remains of a drove of animals that a dozen years before had lost their way in the drifting snow and the dark, taken a short cut over the ice, and fallen through.

Once beyond this, the fertile bottom, with 


\section{GRIM GOES EXPLORING [39]}

black soil, plants and little fish, began again. Then came a new, high-lying land, not stony and rough like the first, but rich and luxuriant. It lay outside a projecting point of land, of which it formed the natural continuation under the water.

On each side of the point a long creek stretched far inland, the scenery under the water being a repetition of that above. A luxuriance and fertility was visible on all sides; the water-grass waved in stretches like corn in the fields, and the giant growths of the water-forests were like the shady trees on land.

On the dividing-line between these fertile regions and the sterile tracts where, on stormy days when the waves ran deep, the drifting sand laid bare old, fish-gnawed skeletons, or covered up new ones, there was a big slough, which formed the beginning of a low-lying, wide-spreading bog, in which the sources of the lake had their origin.

There was always movement in the vegetation here. The mud rose and fell as if waves were passing beneath it. Now and 
then the surface opened, and jets of water as thick as tree-trunks shot into the air. There were high and low jets, forming, as it were, trees and bushes of water, which sometimes burst into bloom with large, strange-hued, fantastic blossoms of foam and bubbles.

In this slough lived the hermit of the lake, the giant sheat-fish $O a$, a scaleless, dark, slimy monster, which only on rare occasions, generally in stormy weather, rose from her mudbed and revealed herself to human eyes. Generally, she moved about on the bottom, living her lonely life of plunder where the law of gravitation ultimately brought everything that was no longer able to swim or float about.

Centuries earlier, pious men had brought her progenitor, wrapped in wet grass, here to the lake, and planted the family of Silurus outside their cloister walls, so that its oily, digestible flesh could serve them as a good dish for fast-days.

The experiment was only moderately successful, and this hardy old fish was the last of her race. 


\section{GRIM GOES EXPLORING [4I]}

Oa had the body of an eel, but was as long and thick as a boa constrictor. If she were ever caught, and placed upon a wagon, her tail would hang out beyond even the longest wagon-perch.

Her head was large and squat, with a huge shark's mouth and small, blinking eyes. Six long, worm-like barbels, whose ends curled and twisted, hung from the corners of her mouth; she felt her way with them as she sedately crawled over the muddy bottom. She had neither neck nor breast, but her capacious stomach hung down immediately behind her gullet, like that of an old sow. It was always distended, and apparently so heavy that its owner's back was quite bent.

Oa was a sinister-looking skulker in dark places, a terror to every poor fish that had been injured and could no longer swim nimbly about.

Like a moss-grown tree-stump she lies buried in the mud when the still inexperienced Grim swims in among the bottom springs, and again and again unwittingly passes over her scaleless, dull green body. She is quite in- 
visible, only the two longest of her barbels projecting from the mud, and incessantly curling and bending like two earth-worms hastily making for the bottom at the approach of an enemy.

Grim, who is always in want of food and cannot resist delicacies, swoops down like a falcon at sight of the "worms," without noticing the watchful gleam in the two little amber-coloured stones that lie quivering on the muddy bottom. She snaps eagerly at the nearest "worm," but it escapes her by adroitly rolling itself up.

The active little pike is still too far off the big pirate's teeth; it must be enticed nearer, so that she can be certain when she strikes.

Grim does not respond to the invitation, however, but prefers to try the other "worm," and.when that, too, with a rapidity unusual in a worm, curls up into a ball and goes to the bottom, she instinctively grows suspicious, and sets her tail-screw going, just as the cunning water-hyena throws off its mask of mud, and makes a wild dash at her. 


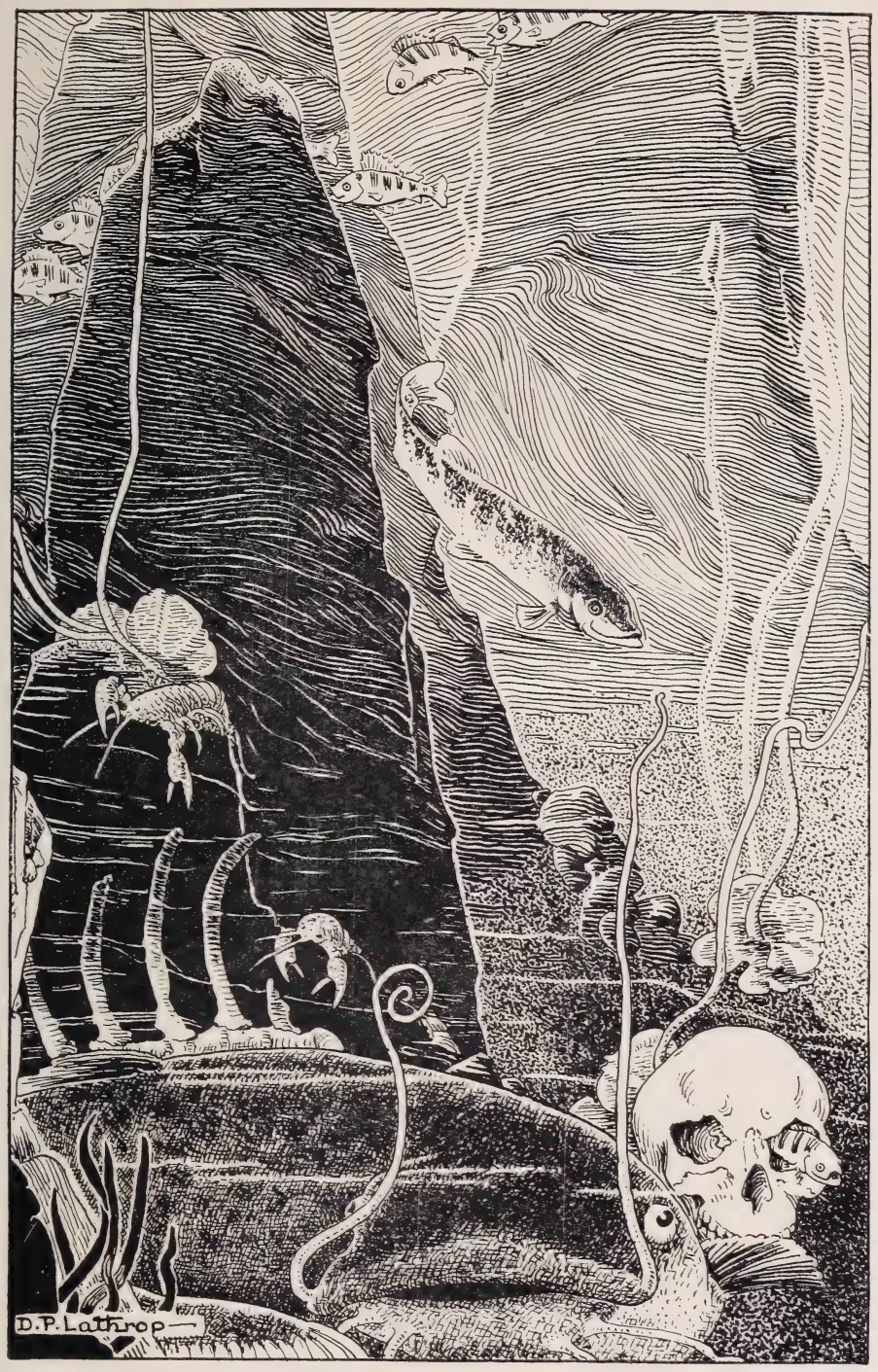

"She snaps eagerly at the nearest 'worm,' but it escapes her by adroitly curling up." 

GRIM GOES EXPLORING [43]

Grim flees precipitately-so terrified that her cold blood almost stiffens-and darts out of the black cloud that $\mathrm{Oa}$ in her eagerness has raised.

The entire hollow seems alive now; everything is gliding and rocking, everything is moving beneath her; she seems to be swimming in black darkness with an angry, gaping, sucking mouth close behind her. She has to keep up full speed with her tail, and to paddle with all her fins, fore and aft, to avoid being drawn in.

When the water begins to clear, and daylight returns, she finds herself in the middle of a shoal of gay little fish, which, at her sudden appearance among them, scatter like a flock of starlings at the dart of a sparrowhawk down among them. She feels the seething and boiling from the quick flapping of tiny tails; and involuntarily she goes with them, swimming away as quickly as the most nimble of the shoal, to a large, wide-spreading island of reeds.

Here Grim remained for a month, during 


\section{[44]}

which time she calmed down, and came to a full understanding of her own cruel, voracious nature.

One day, when she was proceeding along the border of her new beat, she came upon some precipitous cliffs, standing stone upon stone straight up from the bottom, full of holes and openings. She swam into large, slimy-green caverns and lofty grottos. It was the ruin of the old monastery she had found.

For the present she dared not venture back across the lake. The encounter with $\mathrm{Oa}$ had given her a feeling that dangers lurked out in the deep water, to which she was by no means equal. She turned into the nearest creek, and lost herself in a series of large reed-forests. Through them she went on into the bay until the world around her grew narrower and narrower, the surface of the water and the bottom approached one another, and the dreaded element in which she could not breathe made known its superior force by many loud sounds.

Here a great fringe of forest encircled the lake, and Grim turned headlong back. 


\section{IV: THE MARAUDERS}

$D$ ORNE on a gentle breeze, a large crane-fly comes sailing out of the wood. It likes to cool its long legs, as it flies, by trailing them along the surface of the water. The whirligigs are after it, but it easily avoids them. Then comes a sudden surprise: a fish pops up its mouth, and closes its scissor-jaws with a snap on the insect's legs, and it disappears in the centre of a rocking series of rings.

The lake is perfectly calm, its green-black surface smooth and shining, and full of drifting summer clouds. The reeds are reflected in it and look double their height, and the trees mirror their branches there, seeming twice as leafy; and a red house with a white flagstaff on one of the banks hecomes quite a little submarine palace.

More crane-flies arrive, and circle after circle breaks the stillness of the water, just as mole-hills break the uniform smoothness of 


\section{[46] GRIM}

the meadow, as fishes' mouths dart up by the score side by side.

It is in one of the valleys in the submarine mountainous region that this shoal of thousands of bleak lies. It covers the area of a market-place, and makes the water alive for fathoms down.

On the one side rises the forest of weed, like a fir-forest on a Norwegian mountain; on the other the thick green water-grass waves and bends like the corn on some fertile plain in Hungary. In front and behind, the valley winds on between the hill-sides until it widens out and finally loses itself in the barren, sandy desert.

Suddenly, at the end of the neighbouring valley, the water seethes and foams. It is cleft incessantly from bottom to surface, bubbles rise and whirlpools are formed, and a long strip of lake foams and spurts.

It is not like a single large animal darting forward with rapidly twisting tail, and leaving a wake and waves behind it; but a general effervescence that makes the depths gleam with millions of scales. 
It is the perch, the marauders of the lake, on a hunting expedition!

They go together in a large company, like soldiers in an army, rows of them above, beside, and behind one another. There are hundreds upon hundreds of them, and yet a single unit.

With their uppermost layer only a couple of inches below the surface of the water they hasten on. Then all turn at once, changing from the long, narrow marching column into compact formation. A fresh signal, inaudible, imperceptible to all but themselves, and once more, in a trice, the narrow, smoothly-gliding hunting-column is reformed.

Just as they twist and turn in the horizontal plane, so do they in the vertical. They go suddenly and headlong from the surface to the depths, spinning out from their compact mass a long, living thread.

And the thread becomes longer and longer, and thinner and thinner, while they pass through one of the narrows in the submarine mountainous region. 
It is the shoal of bleak they are after. Now they are in the valley where it lies.

The lively little freshwater herring as yet suspect no danger; they are in constant motion, occupied in snapping up the fallen, halfdrowned insects. Noses are pushed up, and little thimble-like mouths open; the water streams in, and with it the food. An eager interchange from bottom to surface goes on; for when the upper layer is satiated, it likes to enjoy its feeling of well-being in peace, until voracity once more makes them all rivals.

The splash of the waves on the surface lifts the gluttons up and down, while the groundswell rocks the satiated to rest.

The perch have quickened their pace; involuntarily the speed is increased; they already scent their prey.

Foremost of the company, with a darkgolden, high-backed leader at their head, swim a couple of hundred of the finest perch. They are at their strongest age, and in best possible condition, suffering neither from too great a weight of fatness, nor from the nervous 
lassitude of insufficient nourishment. They lead, and with frolicsome eagerness push past one another, so as to be the first to arrive.

After them comes the great mass of the horde, big, heavily-laden craft, their round backs and swelling bellies testifying to their success in their toil for material needs. There are perch among them of half an arm'slength, and the thickness of the biggest of wrists. Sheaves of silvery-gleaming rays flicker far out in their wake.

The rest of the fierce horde are large and small mingled-hundreds of perch of half-apound's weight, and rank upon rank of others well over two pounds.

For the present the whole flock keeps to the bottom, darting along with dorsal fin erect, the stiff spines bristling menacingly. It is as well to have bayonets fixed in case of the sudden appearance of a pike.

All at once the van slips away from the rest, and the latter have to exert themselves to catch up, twisting and turning their tails, and unfurling the stiff sail of their dorsal fin. 
There must be nothing now to check their speed; fair-weather sailing is over, and the privateering expedition has begun.

The certainty of booty fills them all.

The vanguard has led the marauders well; they have come under their prey, and now shoot up among the unfortunate, unsuspecting bleak. All order among the assailants instantly ceases, and each member thinks only of its own mouth, and cares for nothing but getting it filled.

Like yellow flashes of water-lightning the perch dart into the shoal of little fish, and like grain among a flock of chickens, masses of bleak disappear into their mouths. They kill and devour-and it will be still worse when the rear-guard comes up.

Now they arrive, and the alarm in the swarm of bleak below spreads with magical swiftness to the upper layers, where the bewildered little creatures make off at full speed. Gleam after gleam flashes up as the little shining fish, uncertain of their way, twist and turn about. Each makes itself as long and thin as 
it can, so as to show as little as possible, and disappear, as it were, in the water.

But now the fierce horde becomes still fiercer. The rear-guard overtakes the fugitives and cuts off their retreat; and smack after smack is heard after their charge.

The swarm of bleak scatters in wild panic. Thousands of them, in their terror, make for the surface, leaping into the air like jets from a fountain. They tumble over one another and try in their bewilderment which can leap highest and farthest. They rise like flyingfish out of the water with a flash, and once more disappear with a splash into the water. There is a splash when they rise, and a splash when they again reach the surface of the water; making a sound like the falling of torrents of rain.

Hell is beneath them in the water! The yellow devils not only menace them from the side; they come upon them from all directions. When they descend in crowds from their flight into the air, they grow stiff with terror on finding themselves face to face with great, amber eyes that seem starting out of 


\section{[52] GRIM}

their sockets to go greedily hunting on their own account. Then a mouth opens, shoots out a pair of concertina-like lips, and changes into a funnel; and the poor little fish disappear into a chasm, like threads into a vacuum cleaner.

Above the spot a cloud of terns is circling. They fly low with half-extended legs and drooping wings, ready to dart down. Sometimes they make a catch, sometimes miss their aim, but have the good fortune to take a fish that inadvertently appears close by; indeed the bleak often leap straight into the birds' open beak. The birds hold them at all sorts of angles in their beak, and fly away with them, shrieking and screaming, pursued by their fellows.

Poor little bleak! they were so pretty to look at. An emerald green colour extended from the back right over the head and nose; and the rims of their eyes when they blinked could sparkle and shine like the gem itself. Their shining breast was whiter than a swan's, and their plump sides gleamed and sparkled like ice under a wintry moon. 
But from the time they left their Creator's hand they were intended to serve as food for others.

A boat lay anchored a few hundred yards off. In it was an elderly man.

An angler this. $\mathrm{He}$ had been out since early morning, and had a delightful day.

Not a single bite. But what did that matter?

He was lying now at the bottom of the boat, dreaming.

He was a regular visitor to the lake. His ancestors' love of a free, out-of-door life had entered into his blood.

It is well known that it takes three generations to make a gentleman; but it would take three times as many to create, out of a race that ever since the morning of time had lived out of doors, a generation that did not care to handle either gun or rod.

In his youth his gun had been his best friend; but the chase demands much of legs and muscles and heart. When a man is no longer in his prime, he should beware of pay- 


\section{[54]}

ing ardent court to Dame Diana. In her suite-it is useless to deny it - the old man is seldom looked upon with favour: he has had his day. But Father Neptune clasps him rapturously in his wet embrace, and sets the fish around his boat leaping and playing.

It was thus in his later years that his fishingrod had become the old man's joy and companion.

Season after season he made his weekly journey from town by rail, and then drove out to the lake. He fished in the good oldfashioned way, talked very little, and was always alone in the boat.

The weather to-day, from a fisherman's point of view, is the worst possible. The July sun is shining hotly, and sends its beams deep down into the water.

The lake slumbers. There is a bottlegreen hue above the deep water, and a lilac shade in the shallows; but over the sandy bottom the colour is drab. Far off a flock of wild ducks rising raise some little, gentle waves, that look so blue, so blue! 


\section{THE MARAUDERS}

The angler, who is a big, sturdy man with large, black-rimmed spectacles upon his voluminous nose, is in his customary fishingdress-an old straw hat with an elastic under the chin, his coat off, and no collar, on his legs a pair of thick, yellowish brown moleskin trousers, his feet in a pair of felt shoes, lined with straw.

He generally stays all day, and it is still far from evening.

$\mathrm{He}$ is now lying outstretched in midday drowsiness, enjoying the great peace that rests on the lake. He has wound the ends of his lines round his wrist; he waits patiently, and if towards evening he is fortunate enough to haul in a pike, he will be filled with a quiet, intense joy.

Suddenly he awakes with a start. He hears a rushing sound like that of the paddles of a distant steamer striking and tearing the water; he sees the terns flocking, and the surface of the water broken again and again by bleak leaping high into the air. He takes up his anchor, and rows up until he hears the smack, smack of the greedy perch all round him, and 
knows he is in the middle of the whirlpool of fish.

He gets four lines clear, and has enough to do in throwing them out and pulling them in. He throws off his hat and waistcoat, and loosens his belt - but even then he is drenched with perspiration.

At last he can do no more, and drops exhausted on to a thwart.

In less than twenty minutes he has caught more than fifty perch, weighing from one to three pounds apiece; they are lying in a brassy heap in the boat.

Then he opens his wallet, takes out the bottle containing clear liquid, and takes a nip. This he is accustomed to do every time he catches a fish of any importance. He drinks to the health of the lake, the lake with the fresh waves and the clear, bright water-the lake that treasures his dearest memories. 


\section{V: THE PEARLY FISH}

DEWEEN a cloudy sky and rough water the wind tore through reeds and rushes.

Grim was lurking at the edge of the bottom vegetation; she had not seen fish-food since the previous evening.

There is a splash in front of her, a broad foot is pushed obliquely down into the water and forces a large, heavy "swimming-bird" past her.

A little later there is a sudden gleam. A small fugitive of a fish darts past as though taking advantage of the wake of the big bird, from one reedy shelter to another.

Grim has already eaten so many bleak and roach that they are beginning to be everyday fare; and now, there goes a new kind of food, a fish that shines all red and green and blue and black, with large, glittering, beady eyes!

At a distance she follows the tit-bit that swims through the water like no other fish, 
turning incessantly round and round on its own axis.

How hard it works! there is a bright starry light all round it, and its tail-fin quivers behind in a long thick trail.

She cannot look at it unmoved. "After it!" say her eyes; "after it!" echoes her empty stomach.

She does not succeed in seizing it across as she generally does, but has to swim up and swallow it from behind in one mouthful.

It is a curiously sharp-spined little fish! Now that she has it in her mouth, it is not nearly so tempting to her palate as it was before her eyes. Well, she has taken the trouble to catch it, so down it shall go!

She cannot get it to move in her mouth; it will not stir! She takes a firmer hold, turns with it, and hastens back into her hidingplace.

Then it begins to bite her in the throat! And now-she becomes quite uneasy-her throat suddenly tries to go the opposite way to her tail! What can be the matter?

She forcibly sets her teeth into her refrac- 
tory captive, when suddenly she is pulled over.

How strange! The simple little pearly fish takes the form of a master, and drags her after it through the water; no matter how much she tries to back, no matter what powerful strokes she makes to force it to obey her will, she is obliged to yield and go with it. Her brain is bursting; she cannot comprehend this powerlessness: the fish is in her mouth and on its way down her throat, and yet it is dragging her along with it.

No! No! And she sets to work and lashes the water into foam with her tail; but the little pearly fish is inexorable; it is too strong for her.

There must be some strange witchcraft about it all!

Instead of her swimming away with it, here it goes swimming away with her, and on they go, nearer and nearer up towards the light and the surface, which she instinctively shuns. All at once the pearly fish leaps into the air with her. She wants to let go, to spit it out, but she is too late; for the moment she is not quite conscious. 
[6o]

GRIM

Her eyes ache; she feels as if they would jump out of her head. Her sight is gone, and a bright red mist surrounds her. She tries to swim, but cannot get her balance; she tries to strike with her tail in order to escape, but the water round her offers no resistance.

A suffocating feeling seems suddenly to contract her gills; she cannot open them far enough. She opens her mouth to let water in, but only swallows dry wind.

The next moment she is lying floundering in a boat, and then a human hand takes her up.

"A pickerel! undersized!" mutters the angler. And he carefully takes out the revolving bait and weighs the fish in his hand. Alas! not even a miserable two pounds!

He takes out his sheath-knife and marks her dorsal fin; and then, in the hope of finding favour with the gods on account of his magnanimity, and catching the fish again at some future time, he tosses her over the side of the boat, and Grim is given back to life.

It was much the same feeling as when she was ejected from the heron's throat; her intestines seem bursting, and her breath to be 


\section{THE PEARLY FISH}

leaving her. Then she reaches the water, where she lies floating on her side, and slowly wakens as though from a long fit of unconsciousness.

And in a trice she has disappeared into the depths.

Her suspicion was aroused. The world was full of villainies, more than those that she herself committed!

Twilight was falling.

The sun's fiery columns, that stood obliquely over the lake, suddenly separated and flowed out, their glowing fragments lying like burning oil upon the surface of the water. Then they were gradually extinguished; the darkness of evening shed its deep blue tones over them.

Long and black, the shadows crept out from the banks; the little fish made their way in to the shelter of the reeds, and the pursuing pike went to rest. And while the surface still sparkled with a peculiar mother-of-pearl brilliancy, the darkness of night already brooded closely beneath the water.

As quietly as a snail, a little crayfish was 
crawling over the bottom; but it was more watchful than a polecat, and listened and felt its way carefully. It came out from the rocky reef, and was now on its way over the sandy plain in to the nearest bank.

Nipper was a robber, encased in coat of mail; he spared nothing that he thought he was big enough to overcome. A sharp, serrated dagger projected above his jaws, and the pincers of his large claws were half-open, ready to fasten upon the unwary prey.

He was a young crayfish, no longer than the span of a child's hand, and with a tail no broader than a finger. His eyes were stalked, and the long, wide-straddling feeling carefully searched the bottom for more than a body's length in advance. The half-closed claws scraped over rocks and water-lily roots in their efforts to drag the mailed body along. Suddenly there was a shock to his feelers. Nipper suspected danger, and struck with his tail; and at once beginning to go backwards, he hastily, with his front claws, stirred up a cloud of mud all round him. Step by step, long and rapid, he hastened, without 
changing his direction, back through the water.

It was only a false alarm, however; there was no otter or water-rat-its worst enemies -close to the tips of it claws. It might take things quietly, and safely set about its search for nocturnal prey again. It stopped beating the water with its tail, and with extended claws and tail outspread, it let itself sink slowly through the water.

Sedately and circumspectly, and with extreme caution, he felt his way before advancing over the bottom of the lake on his clawed legs.

Nipper was descended from an old "backslider" that had been a monster of the order of Decapoda, and had at last become so fat and heavy that she could hardly swim, and preferred to crawl about. Like the rest of her species, she had espoused a new male crayfish every other year; the wedding generally took place in November, when out-of-door pleasures were few, and everything, even the water, was cold and grey.

When the happy honeymoon was over, she 


\section{[64] GRIM}

always suddenly broke off all relations with her spouse, and withdrew into one of the roomiest of the numerous deep, dark, basement flats through the winter, waiting for the sun and the white water-lilies to bring out her little children.

\section{And they came!}

Next summer a swarm of little creatures crept out of the eggs that adhered in scores to her tail. From their birth they had tiny claws, a tiny rostrum, and tiny feelers; and they were all an exact copy of him. Holding fast with one claw to their mother's poorlydeveloped caudal legs, they hung as to a strap, while with the other claw they fought among themselves as much as possible.

It was a little world of malice, cannibal cruelty, and good, healthy egoism that the old monster thereafter dragged about with her, and she defended it - to her praise it must be said-on every occasion against the violence and malice of the outside world, by interposing her own body.

Half without will of her own and unconsciously, she kept life in her young. Every 
time she required food and drew it forward under her body, the baby crayfish got a bit of it. On such occasions they let go of one another, and struck out with his free claw, and hastily transferred the morsel to his mouth.

Nipper had hung to one of the outside "straps" and he was with his mother on the night she went into a crayfish trap. He let go the strap in order to cram himself with both hands, and he did succeed in producing a feeling of extraordinary satiety; but when the trap was suddenly hauled up, he was not quick enough in taking hold again; the water drew him with it, and washed him out through the wide-meshed net. In this way he lost the shelter that in the natural order of things he could still have reckoned on beneath the caudal fan of his great parent; but fate had nevertheless been kind to him. While old Madam Nipper, boiled red like a lobster and with lettuce round her tail, lay that evening curled up on a dish, her little nipper was surrounded with all the wonders of life; and he went at them with greedy claws and flap- 
ping tail. It was not for nothing that he had been born with the art of going backwards.

He had now lived through three winters, and was therefore not altogether lacking in experience of life. $\mathrm{He}$ had successfully passed the age in which his growth of no more than a few weeks made each jacket-sleeve and trouser-leg too short, and had gone through nearly a score of those dreadful "metamorphoses." They were terrible bouts, real illnesses that cost both toil and suffering. The last was still fresh in his memory. He had suddenly become uneasy, could not even rest in his hole. It was the same with them all; the same unrest seized upon all the inhabitants of the crayfish-town that extended over the rocky reef. None of them any longer ventured out at sunset; they remained indoors. Then the illness began with an irresistible desire to scrape and rub oneself. It was impossible to hold out against it; one had to let it go its way and follow a certain system.

The "system" commenced with some wild movements of arms and legs. Resting on the carapace and the big claws, the hind part of 


\section{THE PEARLY FISH}

the body was raised, and the tail spread, and then the thighs, legs, and ankles were worked until a hole was made in the old, armour-like skin, and it split up length-wise.

The transformation took days, so one had to sleep now and then, and rest often. Food there was none.

One started up out of sleep, unable to rest for fear of being left in the old skin and dying of starvation. Nothing for it but to go on, and try to get over this most unpleasant process of moulting as quickly as possible.

Nipper, who was endowed with all the courage and impatience of youth, was one of the most eager to push on the business. He quickly got rid of the armour-plates on his legs, and was now working to get out of his tight coat-of-mail, throwing himself on his back, and rubbing himself backwards and forwards upon the floor.

The coat-of-mail has already come away from the trouser-band, and he can raise it from his body; he presses its stiff edges against a stone, while he works himself backwards out of the old crayfish-case. First he carefully 
[68]

releases both his stalked eyes, then come the feelers, and then the big claws. Oh, but it hurts! And he shakes and twists himself, sweating with exertion and anxiety. After all, it is going confoundedly fast! Suppose a limb got into a tangle, or a joint refused to move! Then it would break, as he very well knows: that kind of thing is a part of the crayfish system!

At last the whole thing was accomplished, and he felt stronger and freer than ever. This evening he would kill! This evening he would eat his fill!

The darkness grew deeper The sinister shadows were already darkening the banks, and the deep water, which before had shone with gleaming mother-of-pearl, seemed now leaden-grey. There was not a water-lily leaf to be seen on the surface; it was impossible to distinguish a single green stalk.

Down on the soft mud, beneath a rotten, wrinkled tree-stump, sat a fresh-water mussel with its shells half-open. As the round feelers of the crayfish came gliding tentatively round its foot, it became aware of the ap- 
proach of an enemy, and had already almost closed its broadly-gaping shells when Nipper, at the last moment, managed to introduce the end of one of his broad pincers, like the heel of a boot in a door. The mussel worked its hardest, straining till its shells creaked and splinters actually broke off in its efforts to crush the hard armour-plating of the claw.

Nipper lay as though petrified in front of his victim, and let the mussel exhaust itself while he watched his opportunity to drive his unimpressionable wedge farther anl farther in. He had the patience of Job, and knew that he only had to wait.

It was not long before he had succeeded in making room for his other claw, and now he was cutting and picking at the body of the poor mussel, one claw holding the pearly shells sufficiently wide apart for the other to convey dainty pieces of mussel-flesh to his mouth.

At last the poor mussel's strength is quite exhausted. It gives up, and Nipper's head and the front part of his body disappear inside the shell. 
Nipper remained there the first part of the night, cramming himself, but at last could not help regretting that a mussel went such a little way. He took a short rest, and then towards morning set out confidently in search of more.

Unfortunately there were no sleepy, unprepared mussels to surprise; but behind some stones in one of the deep, submarine mountain passes stood a solitary fish, which had apparently got out of its course.

The quiet little Nipper had not much experience regarding the way in which a crayfish catches fish; he was more accustomed to snails and mussels. He could also seize a younger comrade in his claws, and suck him dry, leaving nothing but his coat and trousers; but the finned animal, with fans on back, belly, and tail, the nimblest of all-how did one catch it?

He slyly pushes through a crack at the bottom of the cave, raises himself on the points of his closed claws, and blinks with his diverging eyes. He has turned back his feelers so that they shall not betray him while he 
is investigating his immediate surroundings.

Grim is standing motionless with her head towards the current, leaving her forked tail to keep her, with slight movements, on the same spot. She is tired and exhausted after her long struggle with the pearly fish, and feeling rather languid and out of sorts. Her lacerated mouth hurts every time she opens it to rinse it with fresh water. She has, therefore, sought shelter in the rocky cave to compose herself and recover.

Something quivers along her breast and cautiously pricks her sides and belly. It must be a waving grass-stalk!

Then a gradually-increasing, continuous pressure is suddenly felt round the thick part of her tail.

With a sudden movement of her body she tries to shake off the supposed reed, but at the same moment the pressure is felt like a bite from the hard, sharp-edged beak of a heron. She struggles and writhes, and warps herself out of the cave; and now she flies, finwinged, through the water.

Nipper is hanging to her stern. He has 
only hold with one claw, but hopes to get the other, which he is waving about, also applied. His tail-fan works incessantly.

Grim drags at full speed over stock and stone, and swings him out of one gyration into another; through reed-beds and undergrowth, and far, far into the forest of water-weed; but he hangs on still!

$\mathrm{He}$ feels, however, that his prize is rather more than he can manage. There is no time left for him to pick at the fish's flesh with his other claw; he was growing quite dizzy, for he was not accustomed to going forward at such a pace!

Then he stretches out his free claw to seize hold of a root, and thus try to chain his captive to the bottom.

But the trick does not succeed. The jerk that follows is so violent that he loses his claw!

He has now lost his chance, and lets go.

Grim feeling herself relieved of his weight, and free in her movements, darts away with the speed of a run-away engine. In addition to the soreness of her mouth, she now has a 


\section{THE PEARLY FISH}

pain in her tail. She will need some time to recover from both.

Things had gone against her, and to tell the truth she did not think there was much fun in being a fish; but then she had to learn her lesson, and once bitten, twice shy, both in and above the water.

The recollection of the strange little pearly fish long remained in her memory. Its stiff body, and continual turning about its own dorsal fin, without a single stroke of the tail, were long imprinted on her mind; and whenever afterwards the "tit-bit" appeared, her wounded mouth assured her voracious stomach that it was wiser to refrain. 


\section{VI: THE MAN-ROACH}

T Ears went by; and Grim grew into a splendid fish. Her long, flat forehead was now continued straight into the strong duck-like beak of the upper jaw. A hollow in the middle enabled it, as it were, to project in canopies that hung down over her eyes, which thus acquired an expression even more cruel and scowling.

The cheeks stood perpendicularly on each side of the forehead, and enclosed the cranium as between walls; it was as though she had had a dent on both sides of her head. The back of her neck swelled up like that of a bull, for here the muscles lay over the cranium in large, thick curves, until down by the neck, they gave place each to its branchial cleft, which was as large as a barn door.

And what a mouth! It opened up far past the eyes! Generally, it only stood ajar; but to look into it when it opened wide was like looking into a barrel studded with nails. 
In the front of the lower jaw, the teeth stood thick as pins in a pincushion. They were small and pointed, and sloped backwards, so that they served as barbs. In along the sides came the long, widely-separated incisors, whose purpose was to enter into and hold fast the prey. They were more than half an inch in length, rounded and blunt, and resembled the teeth of a rake.

The upper jaw was provided with a far more terrible armature. Whole rows of harrow-like teeth stood out, making a diabolical grater of the palate. They continued far down the throat, and even came forward over the tongue. Woe to the body that became jammed here! It was only released as mincemeat.

But the throat that swallowed the victim was by far the most horrible contrivance.

It resembled the drawn-up mouth of a sack. Down through it lay great rolls of swallowing-muscles, studded with grasping protuberances. In the midst of them the œsophagus was discernible, its aperture incessantly open- 
ing and closing with a suction that inexorably drew everything down with it.

And her external equipment corresponded to her internal. The wonderful, dark colours of the shallows drew a broad stripe along her great back. About the forehead and along the back of the neck, the water-grasses had laid a ground-wash of their own deep green; and her sides were veiled by the flickering streaks of the reed-beds. Patches of gold, like the sunshine falling through the glassy surface of the water, shone out between the trans-verse stripes on her sides; and over the branchial arch and the belly lay the pure whiteness of the water-lily.

Yes, she was adorned in all her splendour. Her scales gleamed with the rays of the sun and moon; and when, with the rapidty of lightning, she made a dart, it seemed like the twinkling of stars in the dark night of the deep waters.

From this time onwards, her voracity knew no bounds. The desire for food, which she had possessed from her earliest days, and which had lain like a germ in the very heart 
of her nature, was given free play by means of the terrible weapons that Nature had placed at her disposal. No one else should now get a bite; she would be alone in clearing the waters of food.

She now as readily seized her prey lengthwise as cross-wise; indeed, she even preferred, when hungry, to make straight for the head; by so doing, she wasted no time in turning it, but could swallow it at once.

By nature she was very reserved, and had no desire for companionship; but her mental abilities were by no means small, and she was well able to make various observations, and profit by their lessons. Nor was she deficient in memory, as she distinctly showed every spring when going to spawn; she always found her way up the brook to the wide fen.

She was very sensitive to every movement in the water, and in a way heard with ease the boats, "the big birds." They always splashed so much with their oar-feet, or whisked their tail round in the water. She had often wondered at them! She had discovered that, like the grebe, they carried their 
young on their back; and, like all the other fish in the lake, she supposed them to be a part of the unrest up on the surface.

Long before they came near her, she was distinctly aware of their approach.

If she were high in the water, and the bird suddenly rushed down towards her, she darted to one side and hastened out of the way. It was different when the boat came slowly gliding along; then she only moved so as not to be run down.

But it was many a day before she came to understand that it was they especially who wanted to harm her.

One evening the old angler was rowing home late from his fishing-ground. The moon had risen, and shed her silvery light around his oars. They dipped down rhythmically, and came up with the silver dripping from them. Suddenly he noticed that one of them struck something, and the shock passed through the oar up into his arm. He was dragging something heavy, and could not bring the oar forward; and then he pulled the head of a pike up above the water. At the 
same moment the fish dropped, and the oar was free; but Grim was wiser after that.

As the years passed she developed into a powerful ruler, and increasingly felt herself to be the divinely-favoured inmate of the lake. She was not one of the rabble! She hunted large and small, and lorded it over the inhabitants of the lake as far as she possibly could.

By more frequent and longer expeditions, she increased her knowledge of the lake, and learned the routes to all the reefs, creeks and banks; and she ascertained that in certain directions her world was immense. It was only the surface that she shunned, and the deepest depths; for there were great crayfish-to whom the Creator had been so good as to set their maxillary half at the end of a pair of long, jointed claws - and there, too, lived Oa, the dreaded fish-monster.

Grim's territory lay half-way between these.

In the pure light of early dawn, when the night flies and moths, drowsy and intoxicated with their nocturnal visits to the flowers, fell 
by hundreds into the water on their way home; when the swallows relieved the bats, and the whirligigs in the sheltered nooks began their noiseless scurrying over the water, beneath which the water-plants were beginning to appear in green, yellow and rust-red colours; when the day dawned down where Grim had her home, and the wide surface above her was filled with light and radiance - then she hunted most keenly, and felt most voracious, and then there was terror in her splash and snap.

One morning early, a breeze is ruffling the surface of the lake, and winding, whitefoamed currents are eating their way out among black shallows. The terns are diving down after small fish, and along the rushbordered banks the rising sun is treading the water.

Grim is abroad, pushing herself forward like a shadow along the bottom. Her cunning crocodile eyes are turned up so that they project from her head.

A number of roach are thronging about a clump of rushes, examining leaves and stalks 
just as long-tailed tits search tree-tops and bark; they are inside it and outside it, sucking up the water-snails and insects.

Grim stops with a jerk. She scarcely moves her ventral fins, and breathes very gently. At each breath she cautiously opens her mouth and draws back her tongue, thus filling the spiked barrel with water; then she carefully closes it again, shoots her tongue forward, and emits the water through her gills.

The little fish gambol unwittingly close to her mouth. Her upturned eyes look still higher, and see the gleam of their white-scaled bellies.

Now she is ready to spring.

There is just a movement of the extreme tip of the tail. Only the shifting shadowlines that the reeds cast over her body indicate that she is moving forward. She peers about continually, peevishly, and evilly. Only one thing troubles her; she can never decide which fish out of the swarming multitude she will take. True, she has made a special study of the way to direct her attack-as the ardent hunter his aim-where the throng 


\section{GRIM}

is thickest; but the roach are nimble, and she seldom gets more than one at a stroke.

Slowly and imperceptibly she rises, while all the fin-tips wag and wave in lingering enjoyment.

Suddenly a little scarlet roach-eye discovers her black back, which up to the present had looked just like part of the bottom, and they fly away from her in a panic of terror. In one moment the rushy margin is empty.

An accident that may happen even to the best of us! And Grim has to move on to fresh hunting-grounds.

Among the floating forests of green featherfoil go big, broad-scaled bream. They follow close in one another's wake, and lie on the surface, letting the sunlight play upon their golden scales. Their fat bellies with the lobster-red fins, and their large, cod-like mouths, give an impression of simpleness. Yet they are cunning enough, and very cautious in all their behaviour.

Several of them are covered with cuts and wounds on the back and sides, and it is evident 
they have already made acquaintance with a pike's mouth. The body of one of them is still bloody, and threads of flesh and torn scales make it look quite woolly as it moves through the water.

They come from deep down at the bottom, and shine with mud and slime and watermoss. They whisk along with much movement and many strokes of the tail. Reeds and rushes swing and sway as they stop for a moment to rub themselves against them. As they pass through the open water, between the masses of vegetation, where the sun suddenly shines upon their amber scales, Grim hastily conceals herself in the forest of weed.

The pliant water-plants, with their long stalks, accommodate themselves to the current, hanging westwards for an hour, only to turn just as unresistingly the opposite way the next. Stiff collars of leaves, like life-belts, hold up the naked stalks, and form a close, flickering thicket about the lurking lynx. Without the slime on her body, she would never get through.

Soon the fat-bellies are before her; they 
are slouching along in little companies, with a thick, greenish, juicy rim to the corners of their fat mouths.

Her purpose strengthens, her powers are doubled, but she is able to restrain herself: the moment has not yet come.

Not until the last "water-cow" is straight in front of her does she reveal herself; and the water flashes and bubbles as Grim twists and turns in her efforts to come up with her prey.

The flank attack, however, does not come altogether as a surprise to the "cow"; it has been prepared for it in this narrow passage, and therefore kept close to the bottom. As a stone bores its way into the ground, so does it plunge into the mud, stirring up the water, and digging itself in, so that Grim gets only mud and grains of sand between her teeth.

Another accident which only sharpened her appetite and made her ungovernably fierce; and just then a little roach swam past.

Grim started. Her embarrassment at her failure almost disappeared, and she involuntarily stiffened as she stood. She could see 
with half an eye that the little roach, which was limping along without any frolicsome jumps and twists, would be an easy prey.

What luck! Roach were generally lively little fish, and not easily got hold of ; and although they formed part of her daily fare, she had to use all her powers and unfold all her energy in order to catch two or three, at the most five, a day. It was only in May, when they lay in bundles among the rushes, amorously flicking their tails, that she had her fill of them, taking as many as a score in the day.

Now only patience, a little more time to wait; for this time she would make sure of her fish!

Just then there is a movement in one of the clumps of weed. The dusky-hued perch with the high back forestalls her. Right before her nose he darts like an arrow after the fugitive, but hesitates at the very moment of striking, stops, and sniffs.

"Oh! so he daren't! He wants to have the whole company with him!"

Grim's eyes are alight with the eagerness 
of the hunter, and her stiff tongue quivers in her mouth as, with widely opened jaws, she springs upon her prey.

The roach is good enough! It wriggles between her teeth and tickles her cheeks and chin with slaps of its little tail; and yet . . . it has an inexplicable strength like that of a little pearly fish that she dimly remembers.

She grows angry. Is an insignificant little fish like this going to resist her will? The silly little thing is ready to go any way but the one she wants it to go; she can hardly get from one thicket of weeds to the other. She becomes so angry that she feels the blood burning in the back of her neck, and with a sudden vigorous effort, she gives the roach a violent tug.

That helps; the fish becomes manageable, its strength vanishes. She is triumphant. Yes, she knew, of course, how it would be!

Grim had been fortunate in her misadventure. True, it was a man-roach that she had bitten into, but she had fortunately broken the line, and now went off with a long trace dragging after her. She had swallowed the 
bait, but what made her horribly uncomfortable was that in doing so she had got a long, thorny water-plant fixed to her upper lip.

They were the barbs of the triple hook that she took for thorns!

At that moment she sees another little roach shining. It is just as languid as the previous one, and makes the same tempting impression. Instantly she makes a dash at it.

The same comedy was gone through, the same incomprehensible strength in a puny roach, and the same work to get the refractory fish into her power.

Well, she managed it at last; at last she had her mouthful.

This one she swallowed too, but once more she had to spit out something sharp and prickly that hung to her upper lip on the opposite side.

It was a long time before Grim managed to wear away the two triple hooks from the corners of her mouth, and in the meantime she swam about with the rusty things like an extra set of monster eye-teeth sticking out of her mouth. The pieces of line that trailed 
behind her often caught in things and chained her in an incomprehensible manner to reeds and rushes; but at last she pulled out one, and a little later the other, and a hard, gristly, leather-like skin formed where they had been.

She gained some experience from this incident; henceforward, she regarded solitary, sickly-looking roach with keen suspicion. She would still take with confident voracity large roach and small; but she very reluctantly took a halting, languid fish like those that had pricked her so horribly that morning. Their drooping fins and heavy, wriggling flight had fixed themselves clearly in her mind's eye.

Her peaceful youth, in which she had only had the heron and the crayfish and her own kind to fight with, had long since passed, and henceforth she was to see more and more of the angler's implements.

But the old sportsman, whose tackle was wearing out, had to overhaul and renew his stock. It irritated him beyond endurance, and for a long time he felt ashamed of himself. From the resistance it had offered he 


\section{THE MAN-ROACH}

[89]

felt quite convinced that the pike he had lost was at least worth a bronze medal. He would not tell anyone where it lay, but would take it himself when he had the opportunity. 


\section{VII: THE RASPER}

$7 \mathrm{HE}$ horde of marauders were chasing through the lake again, and behind

1 them came the pike. These last did not go together, like the perch, in serried ranks at a furious hunting pace, but slunk along one by one from stone to stone, and from weedy clump to weedy clump.

Grim is with them, and like a seal she helps herself to the flying bleak which in their terror rush blindly into her jaws. It is quick work, but nevertheless not quick enough. The gluttony of the perch angers and irritates her; she feels her belly growing larger, and her throat widening. She has room for more fish, mountains of fish!

With a jerk of her body she comes nearer, and is now right in the whirlpool of bleak and perch.

Quivering and trembling, the little fish fly in all directions as she tears among them, and 
with strong beats of her tail to right and left pursues her victims. Her eyes gleam, and her thin lips quiver with insatiable desire.

A big, high-backed perch cooly makes a capture right in front of her. In his eagerness he makes such a commotion in the water that it looks as if it were full of thick, shining snakes. Snap! Snap! There goes a bleak right before her nose!

This is more than she can endure! She dislikes this insolent lake-dog in a still greater degree than when, as a young pike, she stayed in the shelter of the creek. His cunning and deceit, his ability to save himself and to get her into a scrape, has of late frequently irritated her.

A moment later, while she is in the middle of a spring, he happens to be pushed by his comrades right in front of her mouth. Her jaws are already opened, and the water is streaming in like a mill-race; she sees the bleak-fat upon the mouth of her plump opponent, and her ferocity and murderous lust are doubled.

Then she gives way to the innermost need 
of her being. With an enormous development of energy, intoxicated with the joy of capture, she attacks the Rasper with the full strength of both her serrated jaws, opening them so wide, and dashing at him with such force, that they engulf him to far down his plump hog-back. The hundreds of little teeth with which her palate is paved have the same desire, the same purpose; to bore right in and hold fast.

Just as the pike's attack is at its height, the Rasper suddenly raises his twelve-spined dorsal fin. During his chase of the little fish, it had lain neatly folded like a fan along his back; now it is transformed into a murderous weapon, and its bony ribs into a bundle of hidden sword-blades, now stiff and sharp like polished bayonets, now elastically pliable like rapiers.

Joyfully Grim takes the big lump into her mouth. She feels that it pricks her, but the cavity of her mouth is not troubled with any exaggerated sensitiveness.

Splendidly heavy and solid the Rasper feels as he lies upon her tongue! And yet-his 
rough, tile-like scales, and the very small amount of fat and slime on his skin, make it unusually difficult for her to get the lump down.

He is hurting her now. She quickly takes a better hold, even letting her prehensile teeth come into play, and the long board-like tongue warp in co-operation; but no matter what she does, or how wide she opens her mouth, her efforts are in vain: the high-backed one refuses to move beyond a certain point.

Incomprehensible! Impossible!

She tries again. Besides her tongue and her prehensile teeth, she brings the muscles of her throat into play, and the bones of her head expand like a snake's. Colours dance before her eyes as the gullet opens and closes, trying to draw in the perch's head. But to no avail. The wedge remains immovable. The big mouthful is too big!

So there is nothing to be done, but give it up! Grim opens her mouth wide, relaxes her prehensile teeth, which, as readily as an adder's, turning on their hinges, return to the perpendicular; she opens her throat-muscles 
as far as she can, and even pushes with her tongue. "There! The torture in the spiked barrel is over. The prison is graciously open to the great perch."

The Rasper, who, all through the battle, has been lashing out with his strong tail, which is hanging out of the pike's mouth, and throwing Grim from one side to the other, suddenly notices the loosening of the strait-jacket, and backs with a jerk. He thinks he is free, so easily does he swim now, although the darkness before his eyes is just as thick and oppressive.

He is still in the pike's throat, and cannot get away, for he has his twelve stiffest dorsal spines bored into his enemy's palate; and the more he worries and works with his dangerous opponent, the deeper and more firmly do the spines fix themselves.

In the meantime Grim, true to her pikenature, has for a few moments lost nearly all her energy. The spines begin to hurt her, and her mouthful on the whole to incommode her. She cannot get sufficient water over her gills, and what does filter into her mouth in 
spite of the gag, is needed by the gag itself. She can feel it breathing inside her mouth; incessantly, with every indication of excitement, its gill-covers open and close, and take the lion's share of the water.

It is impossible for her to bear this suffocation any longer; she must have air; and in ungovernable rage she begins to lash out with her tail. Now it is she who takes the upper hand, and pushes the hog-backed one before her through the water.

Thus the combat continues. Now it is Grim who has the mastery, and shakes her opponent so that the perch's tail slaps her weakly on the cheeks, and fetches her blow after blow upon the back of her neck. Now it is the Rasper's turn to use Grim as a ferule, running her against stones and water-plants on the bottom, and whirling her round.

But no matter how much they exert themselves, it is without result; they do not succeed in getting away from one another.

Faint and dead-beat, they fall over on their sides. The blood in their red gills scarcely circulates, their strength is ebbing, and there 
is no longer any question of either being leader. They only take it in turns now to spash a little with their tails and try to right themselves.

Grim, who is lying with her gills outside in the free water, is still alive and in possession of all her senses, but the Rasper is half dead.

Then they float up and drift over the surface of the water like dead fish.

Thunder is rolling over the lake.

A scorching sun and oppressive heat have long foreboded the storm that is brewing, and now at last it has burst; the clouds and the water have met.

The celestial salute begins rumbling and crackling a long way off in the farthest corner where the reed-forests rally round the mouth of the brook. The lightning ploughs long, white-glowing fibrous sparks out of the sombre, purple horizon, from which the showers come chasing and sweeping over the lake, casting dark, threatening shadows before them.

Under the fringe of forest on the lee-side, 
where all the grebes have crept together, one of the "big birds" is lying at anchor. She is riding out the storm while the whirlwinds are playing touch over the deep water. She has no lines or fishing-tackle out; she knows well that all angling is in vain.

The water seethes and boils on all sides; the grey troughs of the waves are full of bursting bubbles. Little slate-coloured showers dart about, and plough up the surface of the water like the scratching of a cat on the skin; they dash themselves against the reedy margin and the edge of the wood, cutting broad lanes through them.

All the fish have left the shallow water for the depths where they can lie far enough below the surface to escape the movement of the waves. Only the sheat-fish, the old waterhyena, is out roaming.

The wild weather puts life into Oa; it brings her great opportunities. The fish cannot see in the rough water, they are thrown out of their course, at one moment jumbled together, then separated; and one and another come to grief. It is corpse-weather today. 
The angry waves stir up carrion from the bottom, or carry it out from bridge and bank. She always gets so hungry in stormy weather, and feels as if she must go to the surface for air.

Feeling her way with her sensitive barbels, she glides out of her hole on the east side of the submarine mountain slope. Like a huge eel she wriggles up to the surface, where she lies in wait, slowly drifting with the current.

Grim's white belly is not turned down now. The colour that makes the fish look one with the water would then have hidden her well enough for any one looking up from below. Now her flecked sides and black back make a distinct stripe in the water.

A cunning expression comes into Oa's little eyes. The queer fish with two tails attracts her.

The storm is abating; the last heavy shower is over. A patch of blue sky peeps out like a smiling eye between the frayed, swollen clouds. The lake sinks to rest, and even the pennons of the rushes hang loosely from their 
stalks; but in the distance can be heard the low rumbling of another storm.

The boat takes advantage of the lull, and is on her way home.

$\mathrm{Oa}$, hearing the swish of her bow, has only time to make a few hasty snaps at the big perch's already swollen belly; her thick, fleshy lips are still pulling at the Rasper's intestines as she slowly dives down into deep water.

The gulls and terns, which have begun to gather about the spot, are filled with renewed hope, and swoop down upon their prey with vociferous cries. Involuntarily the angler's attention is attracted to them.

He takes out his glasses, then rows nearer; and in another moment he has the two fish in his landing-net.

What a haul! A pike that has gorged itself on a giant perch! And it can only just have happened, for as soon as he has them in the boat he puts his nose to them and smells that they are fresh.

The perch, it is true, looks rather poorly, but that is probably because the gulls have 


\section{[100]}

been at him already; and he carefully begins to release it, and is greatly pleased when he discovers that the big, voracious pike, which is quite lively, is one of his marked fish.

Grim is furious, and tries to bite and snap while the happy angler makes a guess at her weight by swinging the landing-net up and down in his hands. Ten pounds at the very lowest! No throwing this one back again!

So she was once more in man's power, between his fingers and nails. The light made her eyes prick and smart, the dry air stopped the course of her blood and her scales rose in terror and pain. For the third time she was as it were in the heron's throat!

Then at last she awoke, her sight returned and the breath to her red gills; her brain became clear, and she no longer felt that uncomfortable pressure on the back of her neck. Life was once more coursing through her veins.

She was in water, and with a stroke of her tail she made for the bottom. Oh! She had run her nose against a "stone!" She turned away and tried to go to one side, but there 
was another stone; there were stones all round her.

The fisherman had put her into the well of his boat. She would be all right therefor the present!

The well was full of small fish, which at her appearance immediately crowded together in a corner. She scowled at them, but although her stomach was empty, she felt no desire to eat. She remained perfectly still in the darkest corner of the well, and took note in her own way of what went on around her-the angler's tread on the planks of the boat, his rattling with the oars and gear, his shouts and hailing of other sportsmen gliding past, fastened themselves in her memory. Now and again a "bushy plant" came down and waved its stalks and leaves about her head. She wanted to get away from the bush, and started with a stroke of her tail, but she ran straight into the landing-net. She could not tear the bushy plant, its numerous thick tendrils were so absurdly strong; and it increased her suspicion and gave her fresh experience.

Deep down, Oa follows the boat and listens 
to the ripple of the water against the keeled breast of the great "swimming bird." The old hyena, who had fed on the carrion of the lake for more than fifty years, knew all about the fishermen. With her little blinking, bronze-coloured eyes, that lay floating at the sides of her head, right out where the nostrils are generally placed in mammals, she gives careful attention to the refuse that the fisherman throws out when he cleans the dead perch.

She dares not venture up to the surface. The sun is shining again, and there is no archipelago of water-lily leaves under which she can hide her head. She must wait patiently until her perquisites descend.

She also hears the splashing of the bird, and shouts and strange thumps on the boatplanks; and she keeps her blue-black pupils fixed expectantly upon the great dark shadow up there.

Who knows, some day perhaps a young one might drop out!

As the angler neared the shore he lifted the lid of the well, and stood rejoicing over 
his catch. He saw the pike throw up her head, and was glad to find her still as lively as ever.

And to think that Heaven should at last reward him for his magnanimity! For the mark on the dorsal fin showed distinctly that this fish had been in his hands before.

Grim saw glimpses of the open water from which the dark land-shadows, in the form of the sides of the boat, shut her off. It must be a ditch she had got into, a pool ; such mishaps had befallen her before on her annual wedding-tours up in narrow channels and bogs.

Well then, she knew what to do, and she crouched in a corner, where she lay awaiting her opportunity.

The angler should have replaced the lid before taking his usual nip. As it was, he was standing quietly leaning back with crooked arm, when suddenly, with a tremendous leap, Grim sprang out of the well and over the side of the boat, and with a splash disappeared into the lake.

"Funny thing, very funny!" said a traveller 


\section{[104] GRIM}

a little later in the railway-carriage, to whom the angler had wrathfully related his story.

But the angler himself saw nothing funny in it at all. 


\section{VIII: THE ANGLER'S END}

$T^{\mathrm{T}}$ was so natural for Grim to be once more splashing freely in the lake; it was so

1 natural for her to be feeding on roach again. She should have learned a lesson from her adventure in the air with the man, but the qualifications were lacking.

Her senses, and her power of discrimination, however, had become keener, and she grew more timid and watchful in regard to splashing and noise; indeed, she quite lost her appetite when she was frightened.

The time was past when she would confidently approach the shadow of a boat, she was exceedingly cautious now when she saw the "great bird" on the water.

By this time she weighs about eighteen pounds, and measures the length of a grown man's leg from hip to heel; her dorsal fin measures more than two hand-breadths, and it would take a large hand to span her back. 
She loves peace and quiet, and feels very irritable under the influence of others.

On the approach of storm and bad weather, which she perceives a long time in advance, she generally retires into deep water, where the noise of the waves cannot reach her. She feels indisposed and ill, and remains motionless in her watery lair. Day after day she stays thus, without feeling hunger, or any desire for action. She sleeps and lets all her nerves and muscles rest; only her gills and fins keep working mechanically.

At such times the angler may try to tempt her with spoon or other artificial bait, or with live fish, but she will not touch them! One tempting little decoy-fish after another may whisk past her nose, but both palate and stomach easily withstand the temptations that are placed before her surfeited eyes.

But when the weather calms down and the waves once more grow less, she comes to life again, and is then well and rested. The storm has cleared her blood; she needs food and exercise, and is biting madly. 


\section{THE ANGLER'S END [107]}

One afternoon the angler is sitting in his boat with all his rods and lines out; he is smoking a pipe and listening to the loud "karr-karr" of the grebes.

As usual he is alone in the boat.

He has anchored off his favourite bank, a narrow reef which, in the shelter of the wood, runs far out into the lake. This fishingground, which in windy weather is the richest in the lake, he has discovered himself.

It was hard work getting out to it! The gusts of wind came down upon him unexpectedly as he bounded over the water in his little green-painted boat. Suddenly the lake assumed a wilder aspect, the great wavemountains were broken up into small pieces, and the valleys were filled with wrinkles. The boat quivered, and the angler started and let the main-sail down, while the black wind from the frayed clouds raged under the heavens.

Now the weather is clearing, however, and the lake is calming down-real fishing weather, thinks the angler, and he hums the old angler's song: 
"When the wind is in the east, 'T is neither good for man nor beast; When the wind is in the south, It blows the bait in the fishes' mouth."

The terns, with their long forked tails and black caps rise and fall in the air around him. They are good Samaritans to all the half-dead bait he from time to time throws overboard. The poor little ill-used things hastily make for the shadow of the boat or take up a position beside a floating weed. They want to hide because they feel weak; they do not want to go down into deep water to Oa. Then the terns snap them up, and put them down their little red throats.

Three or four of them are purusing, with shrieks and snarls, another which is flying away with a little bleak, like a piece of white stick in it jaws. It reminds the fisherman of a heron he once shot at, and which sent out a shower of such half-dead little fish.

At that moment he has a bite at one of his lines. The line runs off the reel at a great pace, and the rod, which rests on the rowlock, but with its thick end wedged under a 


\section{THE ANGLER'S END [109]}

board at the bottom of the boat, bends like a flag-leaf and dips its point down into the water.

He seizes the rod and lifts it. The line is running out at full speed. $\mathrm{He}$ carefully checks it, making the resistance stronger and stronger, so as to prevent the fish from breaking the line with a sudden jerk.

Grim has taken the bait, and is now darting about with it. She had been hungry after three days' storm and wind, and had therefore rushed blindly at the lure. Alas, it is another of those prickly fish, she notices at once, one of those confounded tit-bits that are only to be looked at, but which neither teeth nor throat are ever glad to deal with; and she opens her mouth and chokes and spits.

She gets rid of the fish she had snatched; she sees it, half dead and with long rents in its sides from her teeth, floating on its side with a reddish yellow eye turned up towards her through the water. But the prickly thorn that she took in at the same time is fixed in her jaw.

She darts hither and thither, turning and 
twisting. Now she is down in deep water, rubbing her wounded mouth upon the bottom, now she darts, with the bubbles in her wake rising above her, round a clump of waterlilies.

The angler sees an island of leaves as big as a dining-table disappear.

Then she is off again. The reel shrieks and hums as if a giant grasshopper sat chirping in it. All at once, Grim leaps out of the water high into the air, so that her golden, black-streaked body, with the panther-like spots and the trickling water-drops, casts a gleam over the lake.

Never had the good man seen such a fish! The very waves that it raises as it returns to the water, breaking the surface like a submarine, show him that it is - as he is accustomed to express it - "one of the good oldfashioned sort." He continues to gaze openmouthed at the place where it disappeared, while a flurry of rings spreads out in all directions.

A little later a whirlpool appears on the seething water, and he catches a glimpse of 


\section{THE ANGLER'S END [ [ III]}

a dorsal fin with the hinder point missing. Then the old fisherman rejoices. A marked fish, one of his oldest, perhaps his biggest!

He winds in, lets the line run out, and winds in again. His big body is perspiring with his exertions, and he has to stand with his legs wide apart and his feet firmly fixed whenever the mighty fish gives one of its sudden jerks.

While this is going on there are bites on two of the perch-lines, and the angler can see they are not small fish either. The lines, which are lying loose over the gunwale, run out at a great pace, so that the winders hop and dance about at the bottom of the boat. One of them is jerked over the edge, so that fish, hooks, and line are lost; the other he tries to make sure of by setting his foot upon it.

Like the back of a cat about to spring, the rod bends under its floundering burden. The old man has to keep on incessantly slacking and tightening the line; hoping to tire out the fish that was dragging his rod from one side to the other.

He notes the smallest movement of his cap- 
tive. It is still in full vigour, and there are many water-plants and stalks in the way. Will he be able to draw it from the deep water with his fine, fragile line?

Suddenly Grim turns and darts in beneath the boat with such force that the rod must either break or follow her. The angler chooses to let it go in the hope of picking it up on the other side.

It happens as he expected: the rod appears, floats up; he leans over and reaches it.

The fight and nervous excitment recommence-the quick, exciting contest between man and fish.

The wind plays its autumn hymn upon the rushes, and ruffles the water between the yellow-spotted water-lily leaves, while the sun's rays, as they come and go, light flaming torches among the trees and reeds. They gleam, they sparkle, they flash; and great, heavy, September clouds drift over the lake.

At last the shrewd fisherman has the upper hand, and cautiously draws his captive close up to the boat. He bends down, with his 


\section{THE ANGLER'S END [II3]}

knees upon the gunwale, and leans over with the landing-net, in his right hand.

Grim suddenly finds herself close to the great "water-bird," and gives a violent jerk. The fisherman reaches out with his arm, and the upper part of his body as far as they will go; but he forgets that he is in a boat and on unsafe ground, loses his balance, and falls overboard with a splash, upsetting the boat as he does so.

No one sees the accident, and his heavy waders drag him quickly down.

Grim darts this way and that, winding the line round him and drawing him to the bottom. And then, among the rocks of the reef, the line breaks; the angler's body drifts in among the reeds.

Towards evening the sky becomes overcast and the troubled water looks thick and muddy. Little waves leap up, stand for a moment at their height as if trying to keep their balance, and then give up the attempt and roll down.

A solitary little sunbeam still now and again brightens up all the grey-veiled colours, 


\section{[II4] GRIM}

and then the water takes the hues of a fallowdeer, and the water-lily leaves become floating patches of rainbow.

In the muddy valley between the bottomsprings, $\mathrm{Oa}$ is beginning to move. She blinks her cunning eyes, and their blue-black pupils become large and round. Then she sets out on a nocturnal expedition across the lake, steals into the rocky grottos of the cloistercells, and finds a new hiding-place beneath the wreck of a boat-a new arrival. With her snout just in the rent between the bottom and the gunwale, she lies like a dog in its kennel, until night closes in and all is dark and silent.

Then she lets herself slowly drift along the edge to the reedy borders of the lake, taking every drowned dog or cat as gifts from the Creator's hand.

Everything that has no longer the power to keep above the water, all that is dead and drifts about, belongs to the crayfish and to her.

The Nipper had already found the body when $\mathrm{Oa}$ arrived. 


\section{IX: THE WEDDING FESTIVAL}

PRING has come, and the pike are about to spawn. Grim, the great shepike, has been lying motionless for days among the bottom vegetation, waiting the call of the sun. And now it has come. One morning it suddenly bursts through and lights up the forest of stalks in the yellow, weedy margin. In the little open spaces between the tufts there is life and movement, and a sound of splashing everywhere; dark scaly bodies rise slowly out of the water. Then the young fish gambol, their fins beating like wings in the sunshine.

Grim's cold heart, too, feels the spring, and it warms her icy blood. She swims about, full of gentler feelings, she notes an attraction in the shallow water close inshore, the grass of the ditches, and the sheltered pools of the marsh. And suddenly she recollects her bridal chamber, far up at the end of a broad, 
sun-warmed ditch fringed with flowering willow and drooping birch, with flickering sunlight and shadow, and the splashing of lively wooers.

Spring comes on apace, the sun's rays piercing ever deeper into the water, where the plants shoot and rise out of the ooze with herculean strength, mass themselves, expand, and throw wide arms abroad. From the stubbly reed-bed rise fresh stems; and all the fallen willow wands that are floating about put forth leaves and take root.

Soon the banks grow green, and in the sour mud of the creek, where in a short time watersoldiers and duck-weed will form hanging islands, brown toads and green frogs are beginning to bark and croak.

All kinds of fish are gambolling with joy and delight; and at last comes $\mathrm{Oa}$, the old recluse. Without evil intentions she approaches the bank, and in the flaming dawn she lays her hundred thousand eggs among the thronging mare's-tails and grasses. But there is no bridegroom near her, for none exists. Bleak and little roach revel in her roe; 
THE WEDDING FESTIVAL [II ]

and when she has spawned her heart once more grows cold, and she sinks back into the deep water, gloomy and sullen as before.

Grim becomes more and more eager. Her deep-blue pupils, surrounded with a brasscoloured ring, shine like sapphires in an amber setting; the clayey tones along her sides and flanks change to green, and her gill-covers take on a deep orange hue.

Little by little she feels herself attracted by the numerous eager little male pike that incessantly frisk about her, and are already resplendent in their magnificent golden bridal attire. She receives with delight the attentions of the one that for the moment pleases her most; towards the others, and especially those whom she does not like, she is capricious in the extreme, and will eat them if she has an opportunity.

As her spawning-time draws near, she grows heavy and swollen with her roe, and at the same time more irritable and uncertain in temper. She eats nothing, and thinks only of swimming over a flat grassy bottom, where she can rub her distended belly over the soft 
grass, arching her back like a dog in the consciousness of well-being.

The lake, whose banks are for the most part steep and reedy, never tempts her when she is about to spawn. She prefers to make her way up the brook to a number of large flooded peat-bogs and meadows.

She generally reaches them by a roundabout way. At one place where the brook makes a bend and forms swampy ground with miles of reed-forest along its banks, a broad belt of rushes runs through some low-lying meadow-land for some distance. The belt twists and turns, and all the year through, withered rushes lift thin, seedless tassels above the rest. In summer it is grown over, and is little more than a deep bottomless ditch; but in spring, a sudden thaw will swell it to a wide, full channel.

Here, under flowering blackthorn and budding alder-trees, the waters of the bog and the lake are mingled.

One cloudy, misty night, Grim, followed by three ardent male pike, the largest not half 


\section{THE WEDDING FESTIVAL [II9]}

her size, makes her way through the ditch. Other suitors have already appeared; the great migration before spawning is in full swing.

In and out she moves, among the shallows and banks of water-plants. Sometimes there is only a channel in mid-stream to follow, sometimes she has to go through a long, narrow passage beneath an over-hanging bank, until she reaches open, submarine plains in broad creeks. Her ardour and determination to overcome all difficulties help her, notwithstanding mud and a rotting dam.

At last she is through, and swimming about at her ease.

The marsh water shines golden black, with a tinge of bronze. Grim is never weary of rubbing against the soft, muddy peat.

Half-decayed remains of dead stalks form a network all over the great cushion at the bottom, and fresh remains of cell-tissue and organic things just dead are always on their way down. But from the depth new life rises once more; the sun is ever setting free tiny, green, mossy balls of slime that lie moored, as 
it were, to a single fine umbilical cord, and twirl and sway down on the bottom. All at once the cord breaks, and they rise through the water in a cluster like bubbles, and expand into large, fringed umbels.

The willow-wands on the knolls are in flower, and behind the points of land the coots are quarrelling, while the snipe fly round and round in the air, and let the wind play upon their feather-harps.

Then comes the day when she is ready to spawn. A peculiar, and to her inexplicable, desire to bury herself in the rushes and reedstubble fills her, and she likes to run her big body far up among the grass and sedges, where she can scarcely swim or turn. With joy she feels the thrill right up her flanks.

She has never been very sensitive, least of all when it did not concern herself; and now she looks unmoved upon the excited males as they snap and butt at one another. Unfortunately she has no appetite, or she would have eaten the most tempting of them.

The spawning soon begins, and the fish leap one about another in a cluster; Grim loses all 
THE WEDDING FESTIVAL [12I] consciousness of her surroundings, while she sheds her golden stream of five hundred thousand clear, yellow eggs.

No sooner, however, is this accomplished than she comes to her senses, and suddenly feels an overpowering hunger after her tender abandonment. Her gently waving tailfins turns stiff as a wind-filled sail, and with a quick, powerful turn she slips her spiked jaws over the nearest beau, and slowly transfers him to the vacant place within.

Over an hour the wedding-breakfast lasts, and then the great lady swims off complacently with a flap of her late lamented bridegroom's tail still sticking out of her mouth.

Later on, on her way back through the road of rushes down to the lake, her blood is cold and her will dormant.

The spring was unusually dry; the water from the thaw had sunk in at once, and the brook received little additional water; and when Grim reached the old, half-rotten dam, she found it had been replaced by a new one.

Here she remained together with a number of other fish that gradually collected at the 
[122] GRIM

dam, and tried to get through. For two days she was unable to get either forwards or backwards; several times she attempted a leap, but, without success. Then she changed her mind, and went back to the marsh while there was still time.

She was shut in! 


\section{$\mathrm{X}$ : IN THE MARSH}

\section{WIDE stretch of marshland, thickly}

covered with vegetation, and difficult of access, with numerous large pools, full of tussocks and rushes. Century-old peatpits ran side by side, connected with little watercourses or half-overgrown ditches.

Willow and cotton-grass covered the hillocks, and naze and headland ran out into the black water, in which were islands, sometimes fixed, sometimes floating.

Whole little floating fields of frog-bit and pond-weed would shoot out from a bank, and completely cover the bronze-coloured water; green and smiling they looked, and tempted the foot as a trustworthy bridge; but at a single touch with the tip of one's boot, the whole mass quivered and trembled.

Down in the deep water where the black horse-leeches pushed their way along, and monster larvæ with bent back and open jaws 
stood motionless, watching for prey among the refuse, grew the oddest water-forests. They were neither hard nor stiff; their stems consisted of slender stalks held up by the water.

There were bluish green, luxuriant "firforests," and whole groves of palm-like bushes with red flowers upon long stalks. At the edges there were climbing plants, which formed a matted web of stalks and fibres, and bulged out in swelling clouds.

What a curling and bending in everything down there! What pliant shapes! And everywhere there were little, fat, pug-like bastard carp, dozing and opening their mouths without ceasing, making double chins in their enjoyment, and rolling their eyes ecstatically.

From the deep, clear lake with its shining waters, Grim had now come to these low, swampy banks. At first the change was somewhat sudden; but she possessed the ability of her kind to adapt herself rapidly to her circumstances.

Nor did she at first have much difficulty in obtaining food. There were young bream and eels, as well as the "pugs" to go on with; but 
by degrees, as she grew bigger and the years went on, she had to make herself more and more omnivorous in order to exist. She was living, in a way, like a whale in a lake.

In the winter especially things were difficult. In the lake, which had been her home for more than thirty years, it had been easy to manage. It was too big to be frozen over; even in the severest cold the bottom springs kept large areas open. But this was not the case with the marsh, for here the "air," during a long frost, became very close. The water took up the marsh-gas from the decaying remains of animals and plants on the bottom, and could not give it off and renew itself with oxygen.

Grim had then to go where flags and knotgrass pricked tiny, almost invisible holes in the ice. She found them by the gleams of light, and noticed that she could breathe freely at such places.

With this exception she generally kept at the bottom during the cold season, burying herself in the warm, fallen vegetation. There she lay and slept, her blood circulated more 
slowly, and for days together she required no nourishment.

But the torpid state was not complete; now and then she had to move, and then she satisfied her hunger with mussels and snails, and would also examine the mud-shafts of the peatpits.

Here in the muday labyrinths she came upon tench, olive-green fish, with black back. Their scales were very small, and their whole body covered with a thick layer of slime. They were coarse fish, with thick, leathery fins. Formerly she could never endure them, and had made use of them chiefly as a kind of healing remedy when she lived in the lake. When her mouth was full of pricks and scratches from fish-hooks, she would go into the mud to consult them and to get a healing plaster stuck upon her wounded snout by rubbing it against their slimy sides; but now, when hunger sharpened her appetite, she had to turn her former benefactors to another use, and get as much as possible out of the consultation. She therefore ate them wth pleasure. 
In the summer she seldom touched them, but fattened herself on everything that came in her way. She would take a snake that swam across, a frog, a mouse; and if a waterrat made its appearance, she shot up under it, and sucked it in at one mouthful.

In this way she got on fairly well for a few years.

One year, however, there was an unusually dry summer, and in order to find sufficient water she had to move from peat-hole to peathole, and often had to live for weeks at a time in the pools left in the deeper hollows. Fortunately for her, as the water sank, all the inhabitants of the bog gradually came together in these basins. She came across perch and carp; and eels, leeches and toads were also, like herself, imprisoned here, until the rain should once more bring an abundance of water.

She continued to develop, but otherwise than before; ferocity and cruelty were replaced by cunning and ingenuity. And like all the other pike in the bog, she soon learned to swing herself over the ridges from one hole to another, 
and even to cross land for short distances.

She had the choice between dying of hunger and finding an expedient.

It seemed as if that passage, long ago, from the flying heron's beak to the smooth surface of the water had hardened her gills and enabled them to bear the strong, drying oxygen of the air for a longer time; for she often ventured over ridges and peat-dams wider than a high-road.

When she could bear her hunger no longer, she ran herself aground and up into the grass, and then, bending herself together, leaped on in the direction of the new water. As soon as she was in the dry air, she could feel which way she ought to take; the neighbourhood of water affected her sensitive skin and drew her the shortest way. Everything flickered in a golden mist before her eyes, as she crept on, bending and leaping.

It was in the early hours of morning, when the grass was wet with dew, that she made these expeditions overland.

On one of these occasions she got into a large, deep pit, where the crayfish population 
that annually migrated from the lake had their stronghold. All over the perpendicular, blackened sides of the peat-cutting living crayfish claws opened at her.

Day after day for six months she went hunting here, and had enough to do with making her way into the hard, perpendicular walls in which the nippers had their holes. She knew from her experience in the lake that the crayfish could neither steer nor change their course when, with flapping tail, they darted backwards through the water, and were therefore easily caught when once she had hunted them out.

Only one ancient, mussel-scarred fellow, coal-black all over, and with one large and one very tiny claw, eluded her most ardent endeavours. It sat in a rocky hole, far in, its spear-armed head with the stalked eyes resting pensively upon its two unequal claws.

Once or twice it happened that she was aroused from her torpor at night by feeling a firm, hard grasp upon her body, and she darted round in a circle like a dog after its 
tail; but the Nipper always knew when to let go.

One day she was also obliged to leave this hole. She managed to break down the ridge between her and a neighbouring pit, where she enjoyed a few months' ease and comfort. Here she passed the winter, and cleared the mud of every tench, every leech, and every snail.

When spring came she ate everything that came in her way. At this season frogs and toads made their way in multitudes to the pools. The frogs lay croaking and croaking, and the toads barked and growled, all of them full of love and delight, and therefore an easy prey.

Later on she revelled in frogs' eggs, and swallowed great quantities of the fat, black yolks. Sometimes, too, she could feast on some long threads that were stretched about the reed-stubble; they were the eggs of the big toads, threaded like beads upon a string, and laid in the water to hatch.

On the whole she was glad of the frogs and toads; they kept on reappearing, afterwards 
too, when the little tadpoles began to swarm.

She could no longer afford to be fastidious; she had to take everything, and not let a crumb be wasted.

During the summer nights she was busy at the surface. The big, heavy moths, which often, in thoughtlessness or carelessness, settled on the water or on some floating straw, became her booty. She ate them, wings, straw and all, like a hungry man trying to satisfy his appetite with prawns.

No wonder that the teeth in her huge mouth gradually developed into something like the whalebone in the mouth of a whale

But a stomach with the cubic capacity of a hectolitre needed more than this!

The bog is veiled in a steaming mist, which hangs like cloud-lakes over the reeds. The moisture penetrates everywhere, and trembling drops hang from everything; and the thousands upon thousands of spiders' webs show up in all their marvellous workmanship.

Thickets of willow and drooping birches cast black shadows all along the ridges and banks, and large, thick swarms of gnats hang 
silently in the air. Only a leaping fish or a bathing swallow disturbs the deep morning stillness.

The great bog-snail, with its horse-like head and bat-like ears, has come out of its shell and is feeling everything that comes within its reach, groping its way along, and then with a jerk dragging its spiral shell after it. Now it fastens itself to a little dead fish and sucks out its eyes, and finally comes to rest upon the broad leaf of an iris, the point of its shell still trembling with the movement of the water.

A boat-bug that has grown tired, and drawn in its oars, also composes itself to rest. Slowly it sinks to the bottom of the water, where it settles down comfortably and with discrimination among caddis-worms, planorbes, and young salamanders. Even a water-beetle that is in a hurry and, with its head in the mud, is fussing about everywhere, is roughly tossed aside by the powerful palpi.

$\mathrm{Up}$ on the clear surface swims the grebe. Its back is dark, the head, with the beautiful ruffle round its neck, poised high; but breast and belly are a glistening, slivery white. It 
never goes on shore, never even ventures into shallow water; for it must be where it can dive without hindrance. On its back it carries its tiny young, holding its wings protectingly round them as they lie buried in its backfeathers as in a cushioned hollow.

The male swims beside them and dives after food, which he puts into the gaping mouths of the young as they chirp and flap their little stumpy wings.

Grim knows the divers well, and they know her-or so, at least, they think.

This morning, however, in her insatiable hunger, she sets her teeth into a webbed foot and upsets the little boat, so that all the young ones fall out. With the greatest possible speed she gulps down the whole flock, and then, more or less appeased, goes to the bottom, having learnt feathers do not disagree with her at all.

Until next morning she found herself just as hungry again.

Then she was fortunate enough to gain fresh experience about feathers.

In the early dawn, while the rays from the 


\section{[134]

rising sun shed their peculiar colours over the bog, and made it shine with green and yellow, with purple and indigo, she made a dash at a fish on the surface, without suspecting that up in the air above her there was a winged rival, who also desired the booty.

The tern swooped headlong downwards as Grim leaped headlong upwards, and the mouths of the two spoilers closed at the same moment over the little fish. Grim, however, spened her mouth the wider, and closed it with the greater force, and she bit with a voracious violence as great as if she were about to eat the carcass of an ox.

She got the fish and the tern's head in the same mouthful, noticed that she was well laden, and backed downwards, drawing the bird with her into deep water, where she swallowed her strange prey.

What an immense blessing fish with feathers were! For several days she felt so thoroughly satisfied!

From that time she considered every creature upon the surface of the water as her law- 
ful booty. No sooner did a wild duck drop on to the water in its evening flight, than Grim darted up after it from her hole in the mud. At intervals of a day she took both the grebes and cleared the creeks of coots and a couple of young storks that had come for the purpose of learning to fish.

But still the craving for food allowed her no rest. She had to be constantly extending her domain and finding new territory.

See the marsh now that July has come!July, luxuriant, mature, with clouds for hips and swelling breasts, and a sun that seems weary of journeying. Like sea-birds that have no air under their wings for their flight, come puffs of wind, throwing themselves into peat-bogs and marsh-pools. The air is one continuous drowsy hum of flies and gnats; and the reed-warbler is in full voice.

Grim lies dozing in the tepid water, and sees the world above her indistinctly and uncertainly as through thick grass. She only notices that out of the shining blue up there, there now and then appears a little dark 


\section{[136] \\ GRIM}

shadow. It comes down suddenly, pauses for an instant as it touches the water, and is gone again.

It is something alive, she guesses-something for her!

Wherefore she disguises her torpedo-body, and awaits her opportunity.

A moment later the vegetation trembles, the thick masses of sphagnum moss bulge out like clouds, a storm rises on the bottom. The heap of moss lifts, the surface of the water rocks and is suddenly broken by a splash as Grim darts up at the very moment that a swallow, with a graceful swing, skims a gnat off the water.

The surface grows calm, the bubbles float off and burst before reaching the bank, while Grim sinks back into her bed with the bird on its way through her gullet.

The water-beetles and gnats were jumbled together in one muddy mass.

Thus the struggle for food was daily sharpening her wits.

Formerly she had resorted to the islands of water-lilies to catch fish; now there were no 


\section{IN THE MARSH}

fish, but experience had taught her that here the birds came to drink. With her nose just under the margin of the leaf, she stood ready; and she captured many a water-wagtail, now the white with the moon-silvered feathers, now the yellow-yellow as newly-opened marsh-marigolds.

It sometimes happened, too, that she got a wood-pigeon, or a peewit, or a snipe; and once she took an old, full-grown heron. She seized it by the leg and backed with it, drawing it out into deep water, where it drowned.

But the heron tried repeatedly to spit her upon his beak, and in this way she lost one of her eyes. 


\section{XI： TERROR}

T $\mathrm{N}$ the largest of the old peat-holes with their dark brown water, a single large fish 1 could be seen, in bright sunshine, lying motionless among the rushes under the bank.

From time immemorial it had lived in this bog-pool, and seldom left its waters. A wild duck, carrying pike's roe among its feathers, had planted it there long ago.

Terror was not quite so big as Grim, but was longer and leaner, with the head and teeth of a shark.

Many a time had she and Grim fallen out with one another, and fought viciously in their struggle for food. The scars left by their bites lay in deep furrows down their flanks, and were covered with colourless scales arranged in spirals and circles.

Of late, however, they had wisely avoided one another, keeping each to her own large pool. 
During her first year in the bog, Grim had, been followed by several powerful male fish, and a number of younger males swam round about. The second year there were only a few of them left, and in the spring, when the heavens again began to give light and warmth, both she and Terror had been obliged to finish their spawning alone.

Many a happy bridegroom had slipped down their throats; and now, between them, they had cleared the whole bog.

Languid and emaciated, they had now gone into deep water to rest, until the desire for good and abundant nourishment suddenly became intense, and inflamed their courage and foolhardiness.

One morning, before daylight had penetrated into the water, Grim catches a glimpse through it of the swarthy belly of the old fish. Driven by hunger, she has come a little way out of her hole, and is now lurking at the edge of the vegetation just above.

Large pieces of ice and slushy snow are drifting about in the pool, but along the banks and the edges of the tursocks, whither the 
spring has brought flocks of frolicsome peewits, the heat of the midday sun has already made open water and currents.

Suddenly Grim is unpleasantly reminded of her rival's presence by seeing her orange-coloured flanks gleam as she makes a charge, and like a dart she shoots up. As they now meet, after their happily-accomplished delivery, they are both fully aware of the purpose of the meeting: they mean to devour one another.

Fin by fin they set off, scowling maliciously at one another. Grim is close to the body of her rival, and as they move on she pushes her in over the edge of the reeds.

During the winter the reeds have been cut; but the crooked-edge, sharp-pointed stumps are left standing just below the surface, like a stiff brush. The marsh-pike keeps getting her body over the brush, which with every movement tears her tail and belly, and all at once rouses her dull, sluggish nature out of its indifference. She blows up her gills and angrily extends her fins, while a thick shower of sparkling gold and silver scales whirls through the water to the bottom. 
She slips away from the reed-bed, and swift as lightning turns upon Grim, but the old pirate is not to be caught by a bog-trotter. She sacrifices half her dorsal fin, which is mercilessly torn into streamers down the spines.

Then Grim takes a turn under Terror, dashes up from below with open mouth at her opponent, and fastens her teeth in her adversary's belly. Terror tries in vain to make use of her teeth. Again and again she makes the attempt, her saw-toothed jaws opening and closing with a snap. But Grim goes on shaking her, while shower after shower of scales flutter around them in the water.

They roll over one another, the ice-floes break, and thousands of small crystals clink and tinkle. Now they are up in the slushy snow, where the dirty, yellow water seethes and bubbles round their lashing tails; now they disappear in a flickering zigzag down to the bottom.

With the tenacity and energy with which Grim is always animated when after prey, she now wrestles with Terror. She pinches the unfortunate fish, tortures and worries her, and 
keeps it up without interruption. It is not the sort of battle to weary her. She holds her prey between her jaws all the time; it strengthens her purpose, lights the fire in her eye, and encourages her to unceasing perseverance.

The greater the opponent, the greater is her reward and satisfaction. Her stomach desires what tongue and teeth already feel so near; she must succeed in getting this huge morsel-as she once did with her little brother - to lie unresistingly in her mouth, so that she can have the pleasure of turning it about and begin to swallow it.

Terror twists and turns in her efforts to get a bite; but Grim has been fortunate in taking hold so far forward that there is no room left for her to bite. Terror has only her tail-end to strike with, and with it she sweeps up clouds of mud sufficient to hide an elephant.

The battle lasts for more than three hours, and all the ice in the pool is broken into fragments. By this time Grim's miry opponent is exhausted: success has crowned the efforts of the old fratricide, as it has always done in this kind of contest, ever since she was the 


\section{TERROR}

length of a darning-needle. Then in a trice she turns the harassed victim over, and suffocates her by wedging her head into her own throat. But it takes her four days to get Terror through the mouth of her draw-bag. At last she had a fish again that went some way! 


\section{XII: GRIM DEVELOPS}

RIM was now about five feet long, and weighed something like fifty pounds. As with all pike that live in small lakes, her head had grown inordinately. Her daily fight for food necessitated constant use of her head-muscles, which had developed accordingly. In her mouth alone a wooden shoe could easily have been hidden.

The old bright colours along her back and belly were now quite altered. The body vied in blackness with the evil-smelling mud of the bog, and broad, golden-bronze streaks shaded the dull sides. Out in the sunshine she had quite a rusty, coppery appearance.

She was a mythical pike, one of those oldtime fish about which the late lamented angler had told wonderful tales in his day. Even the regular mane of scales of a finger's length, from the back of the neck down over the pectoral fins, was not wanting. 
But her eye was evil, a mixture of yellow and green, cold and deceitful as the foam of the bog-waves; it always shone with a fierce hunger, and even on the rare occasions when the hunger was appeased, the expression of that eye was one of insatiable voracity.

She has succeeded in clearing the bog-holes nearest to her own quarters of every frog, water-rat, and wild duckling; and she has eaten up all the swallows that have come to drink as they flew. Again she has had to travel a good way overland, until at last she has come to rest in a wild, wide pool, which she has never before visited.

Here she has had a fresh, welcome success. She has overcome and swallowed another big, muddy specimen of a bog-pike, even heavier than Terror; the fellow had just bolted a smaller one of his own species, and in it lay a full-grown mallard.

Food! Food!

It is true she always felt her stomach rather heavy, for in the course of time she had got it paved with the most remarkable things. Besides various hooks and wire traces, there was 
a large key that once, in her youth, when she had been standing beneath one of the great water-birds, had come darting like a roach through the water. There was also a dessertspoon acquired under similar circumstances, a plummet, and, lastly, a watch-chain, from the ill-fated angler's vest. All these had, however, become encysted, and were not for consumption; at the very most they were an aid to digestion!

She has been a week over her last splendid catch.

She makes another and another; but after a couple of months she has emptied this bogpool too. What now, and whither?

One evening she works her way in among flowering iris, club-rushes, and marsh-grass, and peers enviously up at the big dragon-flies that are chasing fat flies not an inch above her head. She grows hungrier than ever, and sets to work to devour black horse-leeches in place of eels, and the roots of certain water-plants, which she tries to persuade herself are worms.

In the warm, still, summer evening, the shadows shoot from the banks and ridges, 


\section{GRIM DEVELOPS}

framing the blood-red sunset hues in ebony. Had there been but a few roach left, they would have been playing ducks and drakes over the smooth water.

A reed just beside her moves, and from her hiding-place at the edge of the rushes she sees the reed-warbler flitting about up above. The crafty expression comes into her flat eye; she calculates her distance, and makes a spring.

The first time the bird is too quick for her, but the next time her effort is crowned with success; and the third time she closes her jaws on the reed-warbler's foster-child, a large, redeyed young cuckoo!

Grim was an artist in her way, and had her own peculiar tricks. Since the day when she had leapt out of the angler's boat, she had developed into a regular flying-fish.

Food! Food! The constant refrain both above water and below. To have something in the maw-to have much-as much as possible. Food! Food!

The pool is very deep, with perpendicular, overgrown sides, save in one place where the peat had once been dragged up a slope, mak- 
ing a gradual transition from water to land. The stiff clay is covered with the foot-prints of cattle, and the herbage on the mounds round about is cropped.

This is a watering-place.

Often, when in a famished condition, a transport of hunger which makes her lash her tail-fin round madly in a ceaseless search for food, she has stopped suddenly at the sight of a pair of big, thick legs stirring up the mud. It is a grazing bull or heifer that has come to the watering-place, and has splashed out far enough to be able to feel cool water under its nose.

One day when this occurred, the bigjointed legs and broad chest of the bull inspired Grim with hope, and her over-excited imagination began to conjure up the possibility of at last getting hold of something worth catching.

She steals forward, and her obliquely-set eye, which can look upwards with such ease, fastens, as though cast in that position, upon the great horned head of an ox.

She pushes on among the black cat's-tails, 
hidden under the long-ribbed fans of weed, until she is just in front of the drinking animal, and can see through the glimmering surface of the water the sucking, fleshy nose.

At this she can no longer control her voracity. Where her stomach wills, her body must follow after. Her shrewdness may warn her, and experience urge her to caution, but in vain: when her stomach wills, she rushes into the fray.

The ox throws up its head with such violence that Grim is dragged up with it halfway; but she does not relax her hold, and when she sinks back into deep water, she takes a large piece of the ox's snout with her.

The marsh, with its miles of reed-beds, was a favourite haunt of game, for coolness in the midsummer heat, and for warmth in the winter cold. Here were peaceful spots to hide when chased by men with the report of guns and the barking of dogs. And Grim knew how to benefit by this abundance of game.

Just as it had long been her way to snatch her prey by springing out of her element, so she now created a new means of support by 
lying in wait at the drinking-places like a crocodile.

Several times she molested horses when watering, and on one occasion she bit off half the tongue of a poor calf.

One afternoon a roe-deer comes down with its young. The day is hot, and they run far in, one of them, unable to stop, going in up to its chest. Grim darts up, seizes it by the body, overturns it, and then drags it out with her.

Another day a small dog suffers the same fate. It is caught by the fore-leg and drawn down, while a storm of rings spreads out on all sides.

All she had dreamed of in earliest youth has been realized; no prey is now too large for her.

When she moves slowly in the deep water, long waves rise above her, and whirlpools gyrate upon the coffee-coloured water; and if she shoots up on to the grass after a frog or a water-rat, and churns the water into foam, the whole pool is filled with breakers.

Grim is a remnant of primeval ages, a creature from the time of the great swamps. 
Late in the autumn, when the dock was turning red, and the stiff spikes of the mare'stails were bent like withered grass, black autumn showers filled the marsh to overflowing. The wet mud lay far up over the meadows and pastures, and poured like rivers through the ditches. Pool ran into pool, and the peatcuttings, which lay side by side, only separated by high, narrow ridges, became one huge pit. It was a regular deluge.

Grim swam far and wide, and almost fancied herself in the lake once more. She found her way into new oases where food was abundant, and made great inroads upon the numerous eels and tench that were flocking up from the brook through the ditches and channels. That autumn she really gained ground, and had something with which to withstand the winter.

But one day in October it happened that an osprey that had got out of its course strayed in over the marsh. The morning mist had just disappeared, but the sun was not quite up, when the grey-brown bird was seen sailing high up in wide circles, its mottled breast 
gleaming in the sunlight; and with a black, hooked beak beneath a pair of sharp, sagacious eyes.

The bird had come far and had not yet breakfasted; it came down nearer and nearer to the ground. All the little birds in the reeds began to cry out, and the coots sought shelter in the larger clumps of reeds. Like a kestrel, the bird kept at tree-height above the water, sailing backwards and forwards, keeping a sharp watch below.

There was frost in the air, and the great, hungry fisher probably had a presentiment of the bolt that would soon close its larder. In any case it was quite determined to take both little and big, and leave nothing.

It sailed on perseveringly from pool to pool, over the rushes in the muddy water and the bog-myrtle along the banks, moving slowly, with hanging claws.

Grim comes up from deep water on her morning round, making the most of her time while the shadows still conceal her and veil her movements. Now and again she stops and lies in wait among the water-plants, with her 



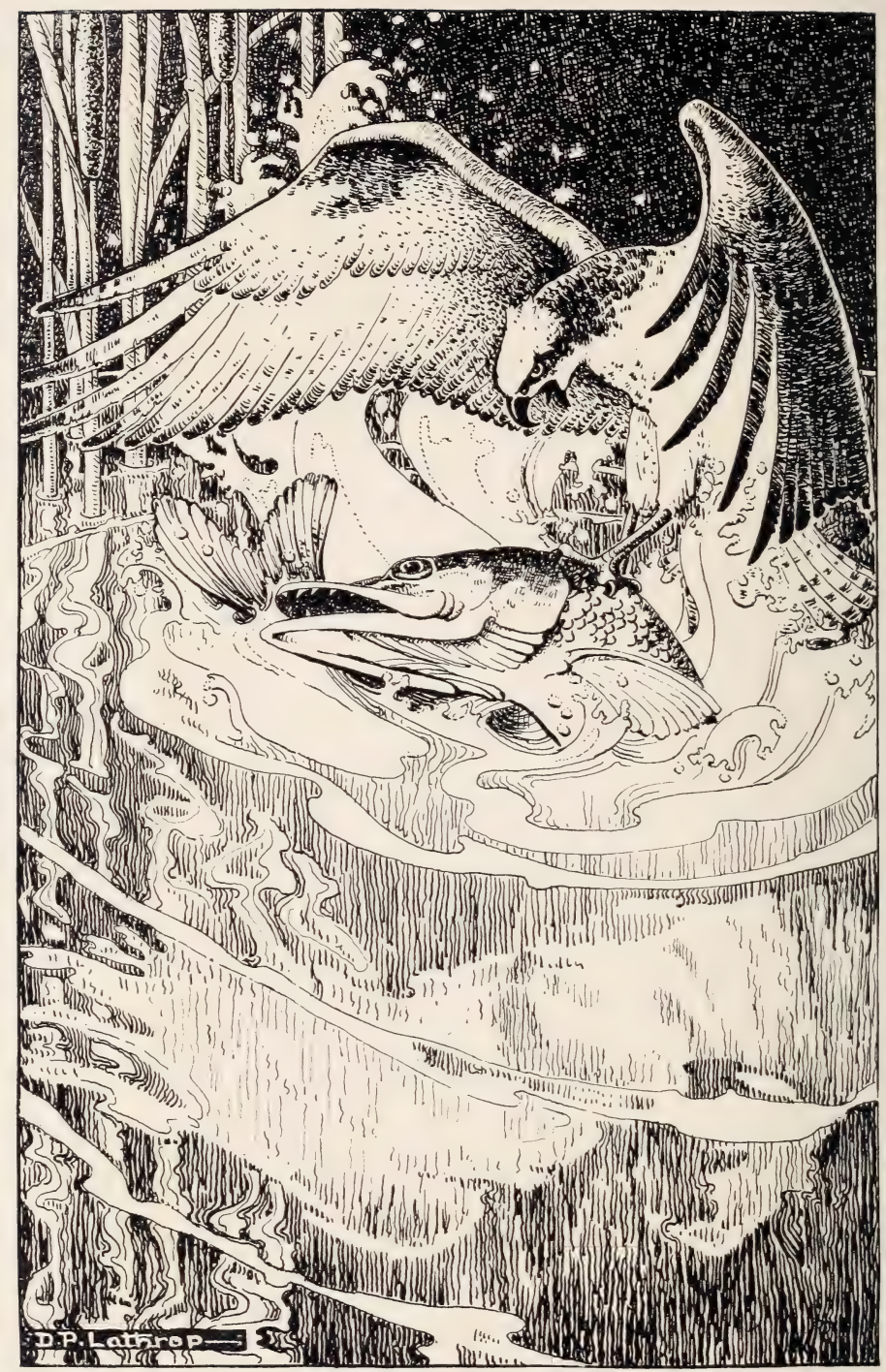

"The bird darts upon her from behind with outstretched claws, and drives them with full force into her back." 
torn, dorsal fin, still but half healed, standing a little above the water.

On one of these occasions the osprey discovers her, and without resognizing what sort of a fish it is, hovers above the spot.

More than once it descends in vain, but is at last successful. Unobserved by Grim, the bird darts upon her from behind with outstretched claws, and drives them with full force into her back. It feels its claws sink in, and the pleasant struggling of something alive.

Its body is partly in the water, but the wings are quite clear, and it flaps vigorously, knowing it must lift its treasure with a quick movement.

A shudder passes through Grim. At the first moment she fancies herself attacked by some scaly enemy, and shakes herself and whirls round, snapping fiercely. But there is nothing to get hold of; the surface of the water seems, as it were, to hold her fast.

The osprey screams and beats his wings, sending up fountains of spray all round. Like others of his species, he is accustomed to master even the largest booty, and he still enter- 


\section{[154] GRIM}

tains the highest hopes and will not let go.

Then all at once danger is imminent! The rash captor notices that the sustaining volume of air beneath his wings is growing less. Now his wings are beating the water. $\mathrm{He}$ tries to get rid of his prey, but cannot get his claws out quickly enough; and the next moment he is drawn down and, to his terror, feels-what he has never quite believed-that water is not after all his true element.

Life is quickly departing from the hitherto victorious bird; the bold flyer, who has darted down hundreds of times and let the water close over his light, oiled feathers, to rise a moment later in a shower of spray and ascend proudly to dizzy heights, now sways, suffocated, ruffled and limp, upon feet whose claws seem rooted in fish-flesh.

Grim lived all that winter with the eagle on her back, and felt strangely hampered in her movements. The bird gradually decomposed, and at last was only a skeleton that sometimes appeared weirdly above the surface. 
In the spring the whole rotted away, but Grim never got rid of the claws. To the day of her death they remained embedded in her back.

She now began to find more dangerous enemies. Her various predatory attacks, which had not all passed unobserved, attracted an ever-increasing amount of attention. In the surrounding districts, where she was spoken of as a serpent and a dragon, myths began to be formed; she had once more to guard against man.

They fired guns at her, and once she got a couple of stray shot in her side, but otherwise escaped with only a fright. Traps were set out, but they were fortunately much too small to allow of her getting into them.

One day she lay burrowing in the mud, so far down that not even the tiniest ripple reached the surface. There were indications nevertheless. From time to time little greenbearded, slime-covered pieces of reed came up vertically through the water, and lay flat as soon as they reached the surface. A farm- 


\section{[156] GRIM}

er's lad, out spearing eels, sent his fork down eagerly. He missed his mark - as the shot had done before.

One day, in the early summer, however, Grim came very near to finding her match. 


\section{XIII: A FIGHT WITH AN OTTER}

7 HE harrier was sitting on her newlyhatched young, and the pair of crows

- were feeding theirs for the last time; it was the time of the owls - and the nightingales. Silent and weary, the cuckoo came from the meadow-land to the bog, where the twilight enveloped it and hid it on its branch.

The willow-thickets and the rushes settled gradually into cool and shade; only along the promontories and banks, where the dragonflies hunted, did the mid-summer sunlight still hold its ground.

The water began to sparkle with strong, bright colours, and patches of yellow, scarlet, and blue floated about, shot with brilliant flakes of emerald and purple, which gave darkened reflections of the birch-tops.

Only a few moments before, all the sloping banks of the bog had been held by the sun; it shone upon the flowers of the wild chervil 


\section{[ 158$]$}

and upon a narrow strip of orange gravel that had been scraped out of one of the banks.

But now it was gone. The fully-opened hawthorn flowers reluctantly gave up their sunset blush, and shudderingly paled before the approaching gloom.

Suddenly the nightingale up in the thicket becomes silent, stops in the middle of its highest trill, and begins to snarl.

A large otter with low-set ears cautiously raises its head above the strip of gravel. It sniffs long and continuously, as it stretches its round, shaggy neck out over the ridge.

Above the distant banks on the other side of the bog, the first glow of the full moon peeps out. Like a monster toadstool, it grows up out of the horizon, sending up a cloud of purple into the air. Up and up it goes, and when almost half its disc is visible, a group of firs, whose tops stand out against it, change to a giant poppy just unfolding.

For a moment the flower stands out perfect, large and round at the end of its slender, black stalk, and then the illusion is shattered: from a toadstool the poppy has turned into a moon! 


\section{A FIGHT WITH AN OTTER [I59]}

Then the otter comes right up out of the earth, with body and tail and four legs, and shuffles down the slope. A couple of herons, fishing at the edge of the bog, bend their necks and make off with hoarse, shrill trumpetings; and a herd of splashing heifers, scenting the approach of a beast of prey, begin to growl and snort.

The otter came to the bog every two or three months, when it was tired of hunting fish in the lake.

A rover's blood flowed in its veins. Nature had endowed it with a peculiarly active power of assimilation, which was probably necessary if it was to keep warm in the cold water; it needed daily its own weight in fish, and therefore had to be incessantly changing its hunting-ground.

It was timid and suspicious, but a great glutton.

Pike, which it used especially to catch in the bogs, were somewhat dry, it is true, but after all, one could not have salmon and trout every day!

After having labouriously shuffled over a 


\section{[160]}

piece of land, and reached the largest of the big pools, it allowed itself to glide noiselessly from its slip-a path trodden in the grassinto its true element.

A few minutes later there was an unusual disturbance in the water, which splashed high up about the dunes and foamed over the banks. A wild chase was going on in the depths, and where it passed the rushes bowed their sheaves and the flags their fans. Black mud was stirred up in whirlpools; seething bubbles came to the surface and burst.

The otter, with a newly-caught fish in its mouth, had been on its way out to a little island, intending to have its meal under a sallow, when it was suddenly attacked and robbed of its prey. It caught a glimpse of the indistinct outline of a great fish, and exasperated at such audacity, determined to go in chase of the robber.

An attempt to get beneath Grim, in order to seize her round the gills or by the belly, was unsuccessful; at the decisive moment Grim had turned aside, so that the otter had to set its teeth where it could. And it needed 


\section{A FIGHT WITH AN OTTER [I6I]}

a well-placed grip to hold such a giant fish. The instant it has taken hold-a little behind the neck-Grim darts into deep water with her assailant. The otter backs, extends his fore and hind legs far out from his body, and spreads his web, so as to offer as much resistance as possible. Just as the weasel lets itself be carried away by the hare in whose neck it has fixed itself, so now the otter allowed himself to be dragged through the bog by the lynx of the waters.

Grim soon sees that this pace is wearing out her strength, and pauses for a moment.

As she does so, she feels as if an eel were winding its pliant body round her chest. She rolls round, unable to use her fins. She quickly regains her balance, however, frees her body from the pressure, and sets off, with sudden twists, and leaps from the bottom to the surface, turning so suddenly that the fishsnatcher's body swings out and hangs down in the water.

But the otter only keeps a firmer hold. He is used to these desperate rallies, which always become fiercer and more violent as the quarry 
is on the point of giving in. He takes care, however, in turning, not to let any of his legs hang in front of the pike's mouth; he is too well acquainted with the teeth of the freshwater shark!

Up and down, the two well-matched opponents dive incessantly.

Whenever Grim goes to the surface, a puffing and growling is heard. The otter hastily gasps for breath, and tightens his hold with his fore-claws; but when they are on their way down to the depths, and air-bubbles, like silver beads, roll through the water behind him, he has only to hold on and let himself go.

Once Grim is lucky. An old snag sticks up in the water, and, in turning, the otter's body is dashed against it. It sends a shock through the animal, but as Grim for the moment has exhausted her energy and succumbed to one of the well-known fits of weakness common to her species, the otter once more apparently gets the upper hand.

Thus with varying fortunes the battle rages for some time.

They lie fighting on the surface-a golden- 


\section{A FIGHT WITH AN OTTER [I63]}

streaked, slimy, scaly fish twisted into a knot with a dark, hairy, furred body!

Once more there is a pause in the fighting.

Unobserved by Grim, who has just fallen into one of her apathetic fits, the otter endeavours carefully to float the pike up under one of the large mounds, in order to drag her up with an effort of strength on to dry land; but the attempt fails utterly: he is simply unable to manage so great a load.

Now Grim's strength returns once more. With a powerful stroke of her tail, she disappears with lightning rapidity from the surface, and goes to the bottom with her rider, whose merry-go-round jaunt makes his head swim. She is trying to get hold of his leg or body, and therefore twists round with him so that he flaps like a loose piece of strap on an axle; but she is not sufficiently supple to reach him. Her back aches, her flexor muscles hurt. At last she has met with an opponent who puts her judgment, her ingenuity, and her endurance to the extreme test.

Down on the bottom, sticking out from the bank, are the roots of the willow-bushes on 
the edge. In her mad rush down, Grim has come near these, and instinctively seeks shelter beneath them. At full speed she runs her long body into the network and sticks fast, rapidly twisting her tail-screw both ahead and astern.

The otter treads water now on the right, now on the left side of her, and tries, by utilizing the roots as steps, to lift her up with him. But in vain; he cannot even stir the huge fish!

His teeth are still far from having forced their way through; it seems as if, short and rounded as they are, they cannot reach the bottom. But he makes tremendous exertions, whipping his tail in under the peat-bank, while with his hind paws he seeks for support in clefts and cracks. Suddenly he feels one of his feet seized. The grasp tightens, so that his whole leg aches; he tries to draw in his foot, but it is held immovable.

A monster crayfish, that has become so stiff with age that it can scarcely manage to strike a proper blow with its tail, has made for itself, in fear of Grim, a reliable place of refuge in 


\section{A FIGHT WITH AN OTTER [I65]}

the hole. For a long time it has patiently followed the battle through its feelers, and hoped that some morsel would fall to its hungry stomach; now, with gratitude to Providence, it closes its great claw upon the warm-blooded fisher.

A growing uneasiness steals over the otter. He had once been caught by the tip of one claw in an otter-trap. The trap was heavy, and had dragged him under water; and he had only escaped at the last moment. With the grasp on his leg, his lungs begin to warn him, his throat contracts, and his eyes seem on the point of bursting. Up! Up! With or without his prey!

He has let go of Grim, and now makes his escape from the hole with so sudden a jerk that the old crayfish accompanies him; but the dread of water, which no living being that breathes with lungs can quite overcome, has taken possession of the otter. With all possible speed he slips out from among the roots, and is already rising; and as he approaches the surface and finds the blessed light beating more and more strongly upon the mud about 
his eyes, he hastens his flight, until, with an eager sniff, he reaches the surface.

Grim is close behind him, and as the otter lands, there is a loud splash. It would have been all over with the brown beast if the old crayfish, on its way down from the surface, where it had at last let go its hold, had not dropped like a stone straight into Grim's mouth. Grim has now to content herself with sending her opponent a cold, dull, fishy glance, and let the Nipper continue its journey down into her draw-bag.

The wound that the old giant pike had received was not a dangerous one. True, there were two rows of deep cuts made by a pair of thick, round-toothed jaws in the flesh on one side of her back; but they healed like so many others that she had had in her time. Her back, however, was tender for days after, and she found it a little difficult to leap.

The impudent, four-footed fisher never went hunting again in her water-hole. The otter felt quite sure that it was only by good fortune that it had not been annihilated by its great, dangerous rival. 


\section{XIV: THE ANGLER FROM TOWN}

П HE lake had changed since the old angler's death; its former peace and 1 poetry were gone. The big swimming-birds had multiplied tremendously, and dashed about restlessly every day, swallowing the fish by means of constantly improving implements.

One of the latest of these was a ten-horsepower motor-boat, manned by a little, sinewy man, thin and elastic, and with a superabundance of energy. He was a journalist by profession, and editor of a paper; the hurry and unrest of a new age burned in him; whether he wrote or refreshed himself with sport, he did it with the same strength and enthusiasm.

Grim's first captor had been an old-style votary of the rod and line; he loved to cast anchor in some quiet spot, light his pipe, and sit watching his lines. The journalist from town was of the very opposite temperament, 
constantly rushing about and hauling in and making fresh casts elsewhere.

He had taken a house for the summer by the lake, and among the red-currant bushes in the garden he had set up his little aquarium, which contained a couple of crayfish, a few perch, and a young pike.

Every morning he dug up worms for his aquarium-fish, and fed them carefully.

If neither pike nor perch touched the worms, and the crayfish did not take them either when they sank to the bottom, he tranquilly devoted himself to his work all day; but if the reverse happened, then the leading article would be short; the editor was occupied elsewhere.

One day, when he was sitting in his office in town, the telephone rang. His wife was at the other end of the wire, and told him that the pike was feeding like mad.

He thrills at the news. His paper has long had news about Grim, the mysterious monster. The expedition is all prepared, his tackle is in order; he has only been waiting for the signal from the aquarium. 


\section{THE ANGLER FROM TOWN [169]}

A few hours later the enthusiastic little man, after a forced bicycle-ride under the scorching sun of a suffocating July day, finds himself among fragrant iris and bog-myrtle. Accompanied by a local peat-digger, who, from fear of the monster, has armed himself with a gun, he turns off by one of the paths.

The wind is blowing through the local jungle, and rustling its myriads of leaves with a sound that to the editor's ears resembles the continual crumpling of a huge newspaper. The stiff, bluish-green rushes, with their black joints, bend caressingly about him, and the strong, spicy scent of wild mint, mingled with the sharp, acrid vapour from the bog, ascends to his nostrils.

For a moment he stands among the rushes, drawing deep breaths as he listens enraptured to the deafening music of nature. The larks are carolling above his head, and the wild ducks rise with a great deal of splashing and fuss; now a snipe comes sailing past and sinks in a long, concave curve.

A sunbeam finds its way into the jungle, and showers a cascade of shifting, dancing 
patches of light over him. He perspires and pants, and wipes his forehead; he blows his nose after the manner of primitive man; he has once more become the kind of being that the Almighty called Man, when $\mathrm{He}$ placed him on the earth.

At an opening in the rushy margin, where an old, fern-clad ridge runs out into the water, he gets his rod ready.

And now let Grim beware! Here comes a fisherman with shrewdness and intelligence! His clothes are the colour of the heron's feathers, his rod painted sky-blue, and his line is grey-green like the long stalks of the waterplants.

He creeps along the mossy, boggy bank, taking care to avoid all disturbance of the water. The pike is timid, and easily put to flight, watchful and agile; if he only breaks a reed, if he only lets a snail-shell drop into the water, it will perceive him. He finds out places where he thinks the fish is lying, and expectantly drops his bait beyond the edge of the reeds on the point of land.

The peat-cutter follows him at some dis- 


\section{THE ANGLER FROM TOWN [I7I]}

tance. He has strict orders on no account to utter a syllable, and to tread with extreme caution and care. He has his gun all ready, for he is thinking with misgiving of all the stories he has heard about the fabulous "serpent." $\mathrm{He}$ recollects that Sidse, old Anders' girl, has seen it. She was watering the cows when it shot up out of the deep water with a splash, and shook itself like a dog. She had distinctly heard the jingling of the scales in its mane

And Ole, the wheelwright, too.

"Such a head!" he had said. "As big as a calf's! And the skin round the corners of its mouth all in great, thick folds!" As to its eyes, he had said they were yellow like those of a hare.

He must remember to tell that to the newspaper-man.

At that moment he hears a warning whistle, the signal to stop and remain where he is, so as not to spoil possible chances by his sudden appearance.

An electric shock has darted through the 


\section{[172] GRIM}

sportsman, and for a moment he stands as if petrified, in keen suspense.

He has felt a bite, and with lowered rod he slowly and carefully lets out plenty of line.

The pike has taken the bait, or so he firmly believes; but he waits minute after minute, and the line never moves.

Alas! the hook is caught in something! His best and strongest hook, selected from among hundreds for this very expedition! In vain he employs every artifice; he cannot free it. He will have to give up his fishing and abandon the line.

What an embarrassing story to have to tell! People have such nasty tongues. And the peat-digger over there! No, that would be too much! Besides, this suffocating heat has long tempted him to have a bath out here, so he promptly strips and goes in. $\mathrm{He}$ is swimming along the edge of the reeds where there is a little open water, when all at once he feels his left leg seized. It is as though a pair of garden shears had suddenly cut into it!

Involuntarily he begins to shout and kick, but the next moment he is dragged out and 
down towards deep water. He feels the teeth of the monster sinking deeper and deeper into his leg, and is on the point of losing his senses as he cries aloud for help.

The peat-cutter hurries up with all possible speed, just in time to catch the outline of a long, black shadow, working under water. At haphazard he fires off both charges. At the same time the editor shrieks still more horribly, and raises himself in the water. A cold, sharp edge, as of a knife, is drawn along his body, as Grim, frightened by the shots, disappears beneath him.

Other peat-cutters come up, and together they pull the unfortunate editor ashore. The blood is spouting from his leg in several places, but one of the men ties his trouserstrap round it. Some one telephones for a doctor, a carriage is fetched, and the editor is then driven to his home.

The wound was a serious one. The doctor had to wash and bandage it. On the outer side of the calf, the deep marks of Grim's upper teeth were visible, in two rows at a distance of more than a hand's breadth from one 
another, wound after wound, going deep into the flesh. It was clearly the bite from the jaws of some great animal.

The oracle's prophecy that the editor would get a bite had in truth been fulfilled!

This occurrence put fresh life into the stories circulating in the district about the escaped crocodile, or the serpent, or the dragon, that always frequented black bogs.

The monster must be removed. For a long time cattle and horses had not been safe when they came to the watering-places; and now it attacked people when bathing!

What sort of an animal was it?

People demanded that the local board should provide them with an ocular demonstration.

Several of the holes were emptied, but they were the wrong ones. Through others nets were drawn with a team of horses at each end. Grim was almost caught two or three times, and only saved herself by burrowing into the mud, and letting the net pass over her.

Then they set to work to drain the whole 


\section{THE ANGLER FROM TOWN [175]}

bog. They started the old windmills from the peat-cutting time, whirled all the screws about, and pumped the water from one large pool into another.

Grim was imprisoned, and at last lay buried in slush. Had they only gone on for another day they would have discovered her; but, fortunately for her, the wind dropped, and when it seemed to be all over with her, the high dam which kept in the water of the neighbouring pool broke, and all their labour was wasted.

After this the enthusiasm and interest cooled.

Who said it was a crocodile? Had anyone seen it? Was it not more likely to have been an otter? For the local board did not believe in serpents or in dragons! 


\section{XV: LUCK}

T $\mathrm{E}$ climbed over some barbed-wire fences, and in doing so made a large 1 number of ventilation holes in his nether garments.

The primitive fishing-tackle that dangled behind his back consisted of a piece of rope with a couple of beer-barrel bungs for a float, and a length of strong, home-twisted iron wire for a trace. The great hook, which must have been intended to catch whales with, was a clumsy steel one that the village smith's apprentice, who was just finishing his time, had made for him; the rod was a short, thick beanpole.

Little Rasmus was an angler with no shrewdness or intelligence worth mentioning. In his hand he carried an old, battered watercan, in which were his bait-a few bastard carp, caught by trawling with an osier-basket in the village pond. They had not been 


\section{LUCK!}

treated secundum artem; they had not spent the night in a tub under a running tap, and had not felt any salutary coolness of the gills from having small pieces of ice dropped into their tepid water from time to time. No, a little grass and mud at the bottom of the can was all they had had in which to keep themselves alive.

Rasmus tried several, and at last found one that could just flap its tail. From habit, and for luck, he spat upon it.

The pools were smooth and clear in the cool September air. To look down into them was like looking through a magnifying-glass at the bottom, where brown-shelled, fresh-water mussels and white-shelled planorbes were discernible among the water-grass and mosses. The reed-tassels, that had formerly been so blue, were now brown and downy at the tip; and all the flags among the rushes trembled under the weight of their heavy seed-pods.

Rasmus quickly made ready his line and went out.

"Aatch!" cried a snipe, as soon as he set foot in the bog, and a little later he put up seven or 
eight more, which fluttered along in uneven zigzags over the muddy herbage, and then suddenly rose in steep, winding curves. With interest the boy watched them in their rapid flight, saw how they hastened the strokes of their wings and circled round the bog, until one by one they broke from the rank and disappeared in a downward dive.

At the end of a ridge, which ran out in a blunt promontory in one of the pits, he tried a throw, and stood for a little while waiting; but as the bait had found a hole in which to hide, and the big bung-float lay still, he pulled it up, and went, with his rope-line gathered over his outstretched arm, to a new place.

He came into a thicket of meadow-sweet and wild raspberries. Late-flowering blue forget-me-nots covered the ground. $\mathrm{He}$ plucked one, smelt it, but threw it away as the sound of a great splash reached his ear.

By balancing along a plank he got on to a little solitary island surrounded by duck-weed. The plank swayed very much under him, and the island sank alarmingly beneath his weight; but he could see that it had borne peo- 
ple before, and he was on it now! A bushy grey willow grew in the middle of the island, and a spike of purple loose-strife raised its head above it.

Grim was lying in a flat, muddy bay, hidden in a large clump of mares'-tails. A fat, lazy carp was half swimming, half floating in the open water in front of her. Had she not been in the bog with its scarcity of food, the very sight of such carrion would have made her sick; as it was, she took it with thankfulness, and ran at it with such greed that she gulped it straight down, and got a large steel hook far down in her stomach.

For a moment she felt it was an uncomfortable mouthful; the flabby morsel must have gone down the wrong way. Well, she would disgorge it!

But she could not, and there was a thick stalk like a water-lily stem that kept tickling her throat. She was going to spit the stalk out, when she noticed that it was rooted in a tuft of reeds.

"Rubbish!" thought Grim, as she flour- 
ished her fins and twisted her tail; for she meant to get out of this warm corner. She set her teeth and started off. The mares'tails broke and the rushes curtsied as she crashed along; everything rocked-the bank and the bay, the reeds and the island; it seemed to the boy as if a pig were running round and rooting about under the water.

The enthusiastic fisherman in grey-weather cloth, with sky-blue rod, silk line, and running tackle, had never had the luck to catch this monster; and here was little Rasmus with his bean-pole, his steel hook and his tethering-rope, and his tackle held!

Grim pulled at the line till the rod was half under water. The boy had all but let go, when a sudden violent jerk upset him. $\mathrm{He}$ had no time to save himself, and with the rod in his arms he fell into the willow-bush. The rope tightened so that the strands creaked and groaned; but the rod was fast in the bush.

Rasmus thinks of making for the shore by the plank, but sees, to his terror, that the island is afloat. The fish on his hook has pulled 
it away from its anchorage, and is now dragging him out into the deep water. The water bubbles about the rope and foams out from the island, as if it were the bow of a racing-yacht. Sometimes the little raft heels over horribly, so that Rasmus's wooden shoes are filled with water. He has quite given himself up for lost, and is repeating the Lord's Prayer.

In the meantime, Grim is dragging him, like a second Tom Thumb, from one end of the pool to the other. She twists and turns, dives down head first to the bottom, only to shoot straight up a few seconds later to the surface to lash it into foam and waves. Great bubbles and myriads of atoms of horrid, black peat-sediment float like swelling clouds in all directions.

Now and then the boy catches sight of a wrinkled, moss-grown back about as long as a bull's. It looks to him like one of the ancient oaks of the bog coming up to lie and float on the surface.

Gradually, as the large, pointed steel hook enters farther and farther into Grim's intes- 
tines, and makes her cold, red blood flow the wrong way, her movements become less and less rapid.

The water makes things dim; she no longer sees clearly, and runs full tilt into banks and clumps of reeds. She feels delightfully surfeited, and darts about the pool with the sensation of dragging with her the greatest booty she had ever taken in her life. How it seems to fill her stomach! At last, at last she is satiated, so that her throat seems ready to burst and her jaws to part asunder; and all at once she notices the same strange over-burdened feeling that she had had that day many years ago, when in greed she had swallowed the big perch.

Wildly and recklessly she drags on the rope, careering around with her little captor; but every time she jerks him off an island, or through thickly-matted vegetation, she drives the point of the iron nearer to her heart. At last, in the fever of death, she rushes right in to the bank, and runs the boy aground on an island of reeds.

She lies floating just below the surface, and 
Rasmus, who now and then between the waterplants catches sight of her greenish-yellow belly and black-spotted tail-fin, cries out in terror.

The old pike of many adventures is wandering in her mind. Is it the big, black perch that she has at last succeeded in consuming? Is it the bull with horns? $\mathrm{Or}$ is it one of the big swimming-bird's young?

Yes, that is it! This time she has succeeded in getting hold of its long leg, and has at last swallowed it and has it safely in her stomach.

But it weighs her down, so that she can no longer keep in a horizontal position. Yes, she feels that distinctly; it is so tremendously satisfying that her tail is sinking and her head rising, and now all at once she rises slowly and stiffly from the water.

The boy almost goes crazy at the sight, and involuntarily covers his eyes with his hands, so fantastically horrible does it appear. Out of the black, muddy water and the purple, 


\section{GRIM}

poisonous-green plants from which the gases of decomposition release great, bladdery bubbles, stands out Grim's huge, crocodile head, cold and staring.

The flabby, wrinkled skin of the throat vibrates with her violent, convulsive gulps, and the lower jaw of more than arm's length is pushed out beyond the upper, exposing to view the extreme points of a row of long, dagger-like teeth at the shrunken corners of the mouth.

The monster now turns slowly on her axis, her big, expressionless, watery eye, looking, with its dirty grey colour, like an unwashed window in an empty, deserted house, projects, fixed and blind, from her huge head.

The iron has reached her swimming-bladder, and robbed her of the power of navigation. She grows dizzy, and like a great float at the bite of a big fish, she goes down silently and straight.

A man busy ploughing heard the boy's cry, and running up, learned what was the matter: a monster of an animal, that Rasmus could 
not pull up, had sailed over half the bog with him!

The man fished up the plank, and helped the boy ashore. Then he fetched his horses, harnessed them to the line, and drew Grim slowly, but surely, up on to the bank.

She lay that night moored to a birch-tree. Life was long since extinct.

A message was telephoned to the innkeeper, who collected items of news for the editor's paper, "that Peter Jenn's son had caught, under the strangest circumstances, a specimen of the great sea-serpent. It resembled a prehistoric toad rather than a fish of the present day."

The following day the whole district gathered at the spot, and the schoolmaster appeared with a man of science who had been summoned.

"Why, it's a pike," said the professor, as soon as he saw it, "an unusually large and old specimen, it is true, but still only a pike." And it must be confessed that he felt a little hurt at having been called out on so long a journey for nothing. 


\section{[186] GRIM}

For many years afterwards Rasmus was the hero of the village, and from that day he never went by the name of Rasmus Jenn, but was called Rasmus Pike. 








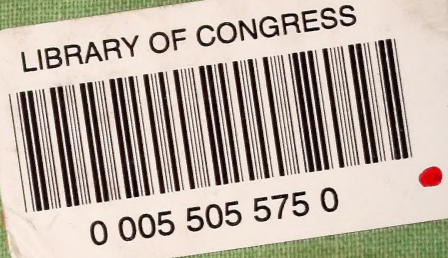

